\title{
ICONOGRAFÍA CLÁSICA DE ASUNTO MARINO EN LA REAL ARMERÍA DE MADRID
}

POR

\author{
MARÍA ISABEL RODRÍGUEZ LÓPEZ
}

\section{RESUMEN - ABSTRACT}

Las armas y armaduras de lujo realizadas para Carlos V y Felipe II de la Real Armería de Madrid presentan una rica decoración cuya iconografía es uno de los medios más adecuados para la exaltación del poder real. El presente trabajo aborda el estudio de la iconografía de asunto marino, basada en los mitos clásicos del mar: sus características formales, los prototipos iconográficos y sus variantes, y su significado profundo, como símbolos parlantes de la soberanía marítima y la garantía de protección del guerrero.

The magnificent arms and armours manufactured for Charles V and Philip II in the Royal Armoury of Madrid, reveal a splendid decoration whose iconography is a very adequate way to exalt the Royal majesty. The present work treats the study of subject marine iconography, taken as a model in the classical Sea myths: formal characteristics, iconographical prototypes and his variants, and the deep meaning they have as simbols of the maritime sovereignty and as the protection`s guaranty for the warrior.

\section{PALABRAS CLAVE - KEY WORDS}

Real Armería Madrid. Iconografía. Mitología. Thíasos marino. Pervivencias Antigüedad. Armaduras del Renacimiento.

Madrid Royal Armery. Iconography. Mithology. Sea thíasos. Classical survivances. Renaissance Armours.

\section{INTRODUCCIÓN}

La colección de la Real Armería de Madrid está considerada como uno de los conjuntos de armas y armaduras regias más importantes del mundo, equiparable a colecciones tan significativas como Viena, Turín o Dresde; sin embargo, faltan todavía por hacer estudios en los que las piezas que integran este magnífico acervo sean objeto de atención desde el punto de vista puramente artístico e iconográfico. Con el presente artículo queremos iniciar una línea de investigación encaminada a remedar ese olvido por parte de los historiadores del arte y hacer una aproximación a las armas de lujo desde la perspectiva iconográfica, atendiendo, en esta ocasión, a la iconografía de asunto marino, tema al que hemos dedicado varios trabajos de investigación ${ }^{1}$. Partiendo pues, de la iconografía de los seres del mar, trataremos de explicar, en cada

1 RodríGUEZ LóPEZ, M.I., Posidón y el thíasos marino en el Mediterráneo antiguo, Madrid, Microted, 1987; Posidón y el thíasos marino en el arte mediterráneo (desde sus orígenes hasta el siglo XVI), Tesis Doctoral, Universidad Complutense de Madrid, CD ROM. ISBN: 84-8466-130-X; Mar y mitología en las culturas mediterráneas, Madrid, 1999. 


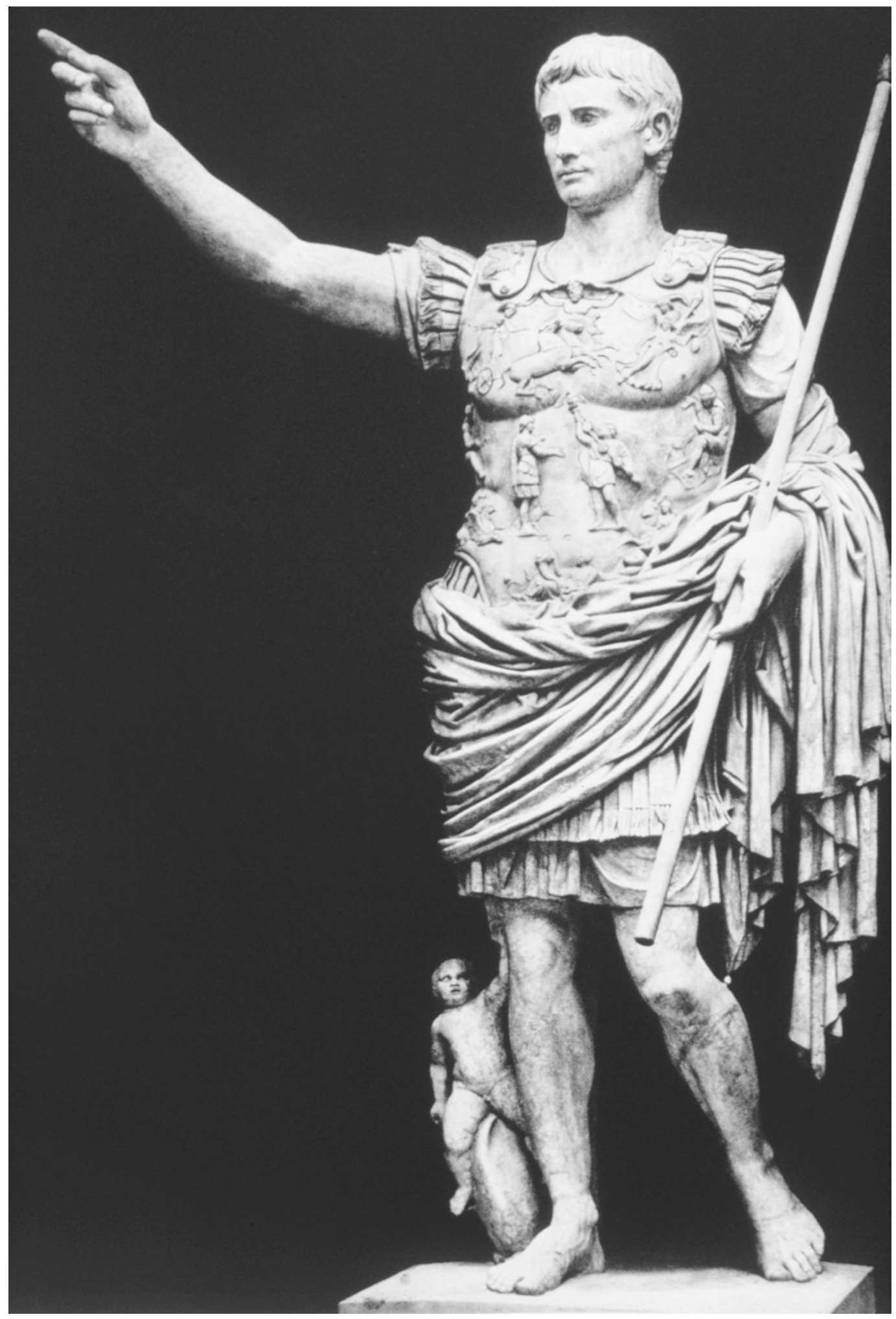

Fig. 1. Augusto de Prima Porta. Roma. 
caso, el simbolismo subyacente en los iconos, reflejos de un mundo intelectual muy elaborado, en consonancia con el ideario de la época en la que surgieron.

Sean mis primeras palabras el reconocimiento a mi maestra, Pilar González Serrano, con quien me inicié en el campo de la iconografía y con quien tuve la oportunidad de admirar, hace ya tiempo, las armas y armaduras que hoy analizo en este trabajo. Quiero expresar, también, mi más sincero agradecimiento a Álvaro Soler que ha facilitado, en todo momento, mi labor en la Armería Real.

Resulta ciertamente asombroso el despliegue de imágenes que muestran las armaduras fabricadas desde el Renacimiento, cuyos repertorios suscitan el interés del historiador, del arqueólogo, del iconografista y de cualquier amante de la obra bien hecha que se acerque al fascinante marco de las armaduras reales. Estas obras, fieles trasuntos de su época, ponen ante nuestros ojos un universo cultural lleno de riqueza y dignidad, al tiempo que vienen a ser una de las manifestaciones más definitorias del momento artístico en el que se forjaron. En el eclecticismo de las imágenes que las adornan, las armaduras nos dejan vislumbrar una compleja simbiosis cultural, en la que se conjugan fe, prestigio, propaganda, herencia cultural e imitación de modelos arcanos y, en definitiva, todo el legado cultural del mundo mediterráneo que Carlos V, primero, y más tarde Felipe II, convirtieron en imágenes distintivas de su mayestática aureola.

\section{ANTECEDENTES}

Los pueblos del mediterráneo antiguo otorgaron, como es bien sabido, un valor de excepción a las armas y armaduras, consideradas como objetos de distinción social desde la Edad del Bronce, y auténticos símbolos del prestigio de los príncipes, sus poseedores. Concebidas de este modo, como insignia dignitatis ${ }^{2}$, las mencionadas obras fueron decoradas de forma más o menos suntuosa, desde fechas muy tempranas, siendo habituales las ornamentaciones de motivos figurativos o vegetales realizados mediante embutido de plata y oro con aplicación de nielado.

Las artes plásticas de la antigüedad clásica ponen de relieve esta importancia concedida a las armas y armaduras, obras finamente elaboradas y decoradas, algunas de ellas fabricadas, según tradiciones legendarias, por el mismísimo Hefaisto. Baste pensar, por ejemplo en las representaciones de Palas Atenea ${ }^{3}$ o en las del belicoso Ares, entre los dioses griegos, o bien en las figuraciones que nos dejan ver las armas de Aquiles, forjadas para el héroe por el dios herrero y entregadas por éste a Tetis, su augusta madre ${ }^{4}$.

2 Cfr. VVAA., El mundo micénico. Cinco siglos de la primera civilización europea. 1600-1100 a. C., Madrid, 1992 , pp. 80,81 y 124.

3 De todas las representaciones de Palas Atenea realizadas en el mundo antiguo, merece especial mención la desaparecida imagen de Atenea Parthenos de Fidias (447-438 a. C.), colosal estatua criselefantina cuya descripción nos ha llegado a través de las fuentes clásicas y de las copias de época romana. La imagen titular del Partenón medía doce metros de altura y estaba ataviada con un peplo y casco áticos. En medio de su casco había una figura de la esfinge y a uno y otro lado del yelmo hay grifos esculpidos en relieve (Pausanias, I; 26,4). En su pecho tiene insertada la cabeza de la Medusa de marfil; tiene una Nike de aproximadamente cuatro codos y en la mano una lanza. Hay un escudo junto a sus pies, y cerca de la lanza una serpiente... en la base de la estatua está esculpido el nacimiento de Pandora (Pausanias I; 24. 5 y ss.). Cfr. PAusanias, Descripción de Grecia (Introducción, traducción y notas de María Cruz Herrero Ingelmo), Madrid, 1994. El escudo de la diosa (reproducido en el escudo Strangford del Museo Británico), estaba decorado con una Amazonomaquia en su frente. Cfr. BLANCO FreIJEIRO, A., El arte griego, Madrid, 1956, pp. 211-212.

4 El tema de las armas de Aquiles forjadas por Hefaisto procede del texto de la Iliupersis. Según el relato de Homero, Tetis pidió al divino cojo que hiciera unas armas para su hijo, con las cuales éste pudiera enfrentarse a Héctor y liberar el cadáver de Patroclo, en poder de los troyanos. Para ello, echó al fuego Hefaisto, el duro bronce, y el estaño, y el precioso oro, y la plata. Y sobre un tronco puso enorme yunque, y empuñó en una mano el pesado martillo y en otra las tenazas. Y fabricó ante todo, un escudo gigante y sólido, con adornos variados, triple franja reluciente y correa de 
La célebre estatua del emperador Augusto hallada en Prima Porta (Vaticano) (fig. 1) constituye, por sí misma, un excepcional modelo de traje militar a emular ya que su armadura thoracata ${ }^{5}$ estaría llamada a tener no pocas repercusiones en el Renacimiento, en las denominadas armaduras alla antica ${ }^{6}$. Dicha armadura está decorada a base de motivos alegóricos que no hacen sino subrayar el poder del emperador, sus triunfos y virtudes: el centro del peto está ocupado por un emisario de Roma, acompañado de la loba mítica, en actitud de recibir las enseñas arrebatadas a Craso por los partos, escena que alude al mayor éxito obtenido por la diplomacia de Augusto. En la parte superior está personificado el cielo, bajo cuya bóveda la cuadriga del sol atraviesa el espacio precedida por dos figuras femeninas que representan el rosicler y el rocío del alba. La parte inferior del conjunto está ocupada por la figura de la Tierra, que se recuesta en el suelo, protegida por las deidades predilectas de la casa Imperial, Apolo y Diana. Tan extraordinario despliegue de medios iconográficos sirvió en la Antigüedad para encarnar al príncipe ideal, como general invicto7.

A través de dichas imágenes podemos corroborar ese ideal de suntuosidad otorgado a las armas y armaduras en la Antigüedad, hecho que se ha confirmado, asimismo, gracias a las piezas proporcionadas por la Arqueología, escudos y yelmos muy en particular. Son especialmente interesantes, en el marco de este trabajo, algunos yelmos broncíneos de época romana, en los cuales los motivos elegidos para la decoración en relieve (mediante la técnica del repujado) son, en muchos casos, de naturaleza mitológica, claros antecedentes de los motivos iconográficos que, como veremos, el Renacimiento habría de utilizar como símbolos de poder y prestigio.

Formando parte del repertorio iconográfico utilizado para tales ornamentaciones, no podían faltar el Gorgoneion, máscarón cuya capacidad para petrificar resultaba ciertamente adecuada para intimidar al enemigo ${ }^{8}$, los grifos, siempre efigies apotropaicas ${ }^{9}$, los amigables y hermosos defines, sobre cuyo simbolismo volveremos más adelante, o la citada escena en

plata. Y puso cinco planchas al escudo. Y esculpió en él una porción de figuras imaginadas con mucha inteligencia. Representó la tierra, y el Urano, y el mar, y el infatigable Helios, y la redondez completa de Selene, y cuantos astros coronan el Urano: las Pléyades, las Hiadas, la fuerza de Orión, y la Osa, que también se llama el Carro y gira alrededor de Orión, y es la única que no llega a las aguas del Océano. Y grabó dos hermosas ciudades de hombres. En una se celebraban bodas y festines solemnes. Y las novias salían de las cámaras nupciales y eran conducidas por la ciudad...Rodeaban la otra ciudad dos ejércitos resplandecientes de bronce...Después, siguiendo todo el contorno del escudo aquel, labrado de un modo admirable, represento Hefesto la gran fuerza del río Océano. Y después del escudo grande y sólido construyó una coraza más refulgente que el esplendor del fuego. Y construyó también el casco, duro, hermoso, adornado y a medida de las sienes del Peleida, empenachándolo con áureo airón. Y después construyó las grebas con flexible estaño (Ilíada, Canto XVIII, 475-614). Dicho asunto, ciertamente extraordinario se difundió en las artes plásticas, desde la segunda mitad del siglo $\mathrm{V}$ a. C., como atestiguan numerosas piezas cerámicas, relieves, espejos, mosaicos etc. Cfr. RODRÍGUEZ LóPEZ, M.I., Posidón y el thíasos marino en el arte mediterráneo (desde sus orígenes hasta el siglo XVI), Universidad Complutense de Madrid, CD ROM. ISBN: 84-8466-130-X.

5 Para más iformación sobre armaduras thoracatas, véase ACUÑA FERNÁNDEZ, P., Esculturas militares romanas de España y Portugal, I. Las esculturas thoracatas, Madrid, C.S.I.C., Delegación de Roma, 1975.

6 Filippo Negroli es el primero que puso de moda estas armas «a la antigua» en el Renacimiento. Su arte no tiene rival por su extraordinario virtuosismo y la perfecta asimilación de lo clásico. Es en sus obras cuando aparecen, por vez primera, los términos alla antica, alla romana, o all'eroica. Cfr. PYHRR, S.W./GODOY, J.A., Heroic armor of the italian Renaissance. Filippo Negroli and his contemporaries, The Metropolitan Museum of Art, Nueva York, 1998, p. 2.

7 La estatua a la que hemos hecho referencia es una copia de un original algo posterior al año 20. Algunos autores han señalado que el original, de bronce o de oro, estaría en la residencia de Prima Porta, en las afueras de Roma, junto a la Via Flaminia. Cfr. BlanCo FreIJEIRO, A., Roma imperial, Madrid, 1989, p. 18 y ss.

8 Tras la decapitación de la gorgona Medusa a manos de Perseo, la diosa Atenea se sirvió de su cabeza y la colocó en su escudo o en el centro de su égida. De este modo, sus enemigos quedaron convertidos en piedra con sólo ver a la diosa. Cfr. GRIMAL; P., Diccionario de Mitología griega y romana, Barcelona, 1984.

9 Asociados a Apolo o, según otras tradiciones legendarias, a Dioniso, estos seres de cabeza provista de pico aguileño, poderosas alas y cuerpo leonino, fueron considerados en las leyendas antiguas como seres guardianes de los tesoros de estos dioses, por lo que la iconografía habría de convertirles en protectores de cualquier dios o mortal que pudiera contar con su imagen. 
la que la nereida Tetis transporta las armas de su hijo Aquiles. Como ejemplo de lo expuesto remitimos a la decoración repujada de un yelmo de gladiador procedente de Pompeya (Nápoles, Museo Nacional) (fig. 2) en el que, por encima de la visera, sobre la cabeza, han sido repujados, con firme trazo, dos delfines de sinuosa conformación anatómica que flanquean la imagen central y terrible de Medusa. Sobre ésta surge, completando el perfil de la pieza, un prótomo de un animal fantástico (similar a un grifo) que se yergue amenazador ante el posible adversario ${ }^{10}$.

Algunas pinturas cerámicas ponen de manifiesto que los dioses y criaturas del mar formaron parte de la decoración de las armas más suntuosas desde antiguo. Entre otros ejemplos merece citarse un peliké procedente de Ruvo, del siglo V a. C., con el tema de la Gigantomaquia en el que pueden contemplarse representaciones de seres anguípedos e hipocampos en el interior de los escudos que portan los personajes representados ${ }^{11}$. Asimismo, entre las fuentes de inspiración decorativa en las que se basaron los armeros del Renacimiento, en lo que a la temática marina se refiere, destacan algunos frescos de Pompeya y Herculano, la decoración al fresco y los estucos de la Domus Aurea de Nerón que proporcionaron la fantasía a los luego llamados «grutescos», los frentes de los sarcófagos romanos antiguos con escenas marinas ${ }^{12}$, y no pocos pavimentos musivarios, obras de naturaleza eminentemente pictórica en las que la imaginación de los artistas no encontraba límite alguno. En dichos motivos iconográficos, surgidos mayoritariamente en el ámbito del arte helenístico y llevados a su punto álgido durante el período romano imperial, se basarían, recuperando el legado de la Antigüedad, los dibujantes y grabadores, desde finales del siglo XV, para elaborar los repertorios iconográficos utilizados por los armeros.

Los motivos ornamentales marinos más recurrentes en las armaduras del Renacimiento fueron los delfines, los tritones y las tritonisas (o sirenas pisciformes, si se prefiere una terminología heredada del arte medieval) ${ }^{13}$, los ictiocentauros en combate, los monstruos marinos y las figuras de algunos dioses marinos, Neptuno y Océano particularmente. Junto a todos ellos, ocupa lugar de honor la efigie de la gorgona Medusa, también hija del mar, descendiente de la estirpe de los dioses marinos Forcis y Ceto, y convertida en emblema de inigualable sugestión para decoración de los escudos, por las razones ya esgrimidas.

Intentar profundizar en el porqué de estos motivos iconográficos resulta, como veremos, una cuestión no exenta de complejidad, dado que en la mayoría de los casos, su presencia obedece a más de una razón, como compendio y resumen de toda una tradición cultural del mundo mediterráneo basada en los mitos clásicos del mar. A lo largo de estas líneas intentaremos sacar a la luz y clarificar, en la medida de lo posible, el origen iconográfico de estos motivos y los argumentos que justifiquen la utilización de los mismos en las armaduras de la colección real de Madrid, cuyo núcleo principal está compuesto por las armerías personales de Carlos V y Felipe II. Grosso modo, puede señalarse que la presencia de los seres asociados a la mitología marina responde, fundamentalmente, a consideraciones de prestigio y propaganda política, y también a razones simbólicas en relación con la escatología. En ocasiones sus efigies obedecen, simplemente, a una predilección por la belleza de sus sinuosas formas, cuyos juegos caprichosos se adaptan bien a cualquier campo decorativo y pueden satisfacer la demanda de los comitentes más sensibles al encanto o la atracción de la pura forma. Elementos simbólicos y formales configuran, de este modo, todo un repertorio decorativo extraordinariamente rico, en el que la realidad y la fantasía se alían para dar lugar a

10 Este tipo de piezas proceden, mayoritariamente de las celdas adosadas a los muros del fondo del cuartel de los gladiadores de la ciudad sepultada por el Vesubio.

11 Cfr. VVAA., Gréce classique, Universe des Formes, París, 1969, f. 312.

12 RUMPF, A., Die Meerwessen auf der antiken sarkophagreliefs, Roma, 1969.

13 RODRÍGUEZ LÓPEZ, M.I., «Las sirenas. Génesis y significación de su iconografía medieval», Revista de Arqueología, n.211, noviembre, 1998. 


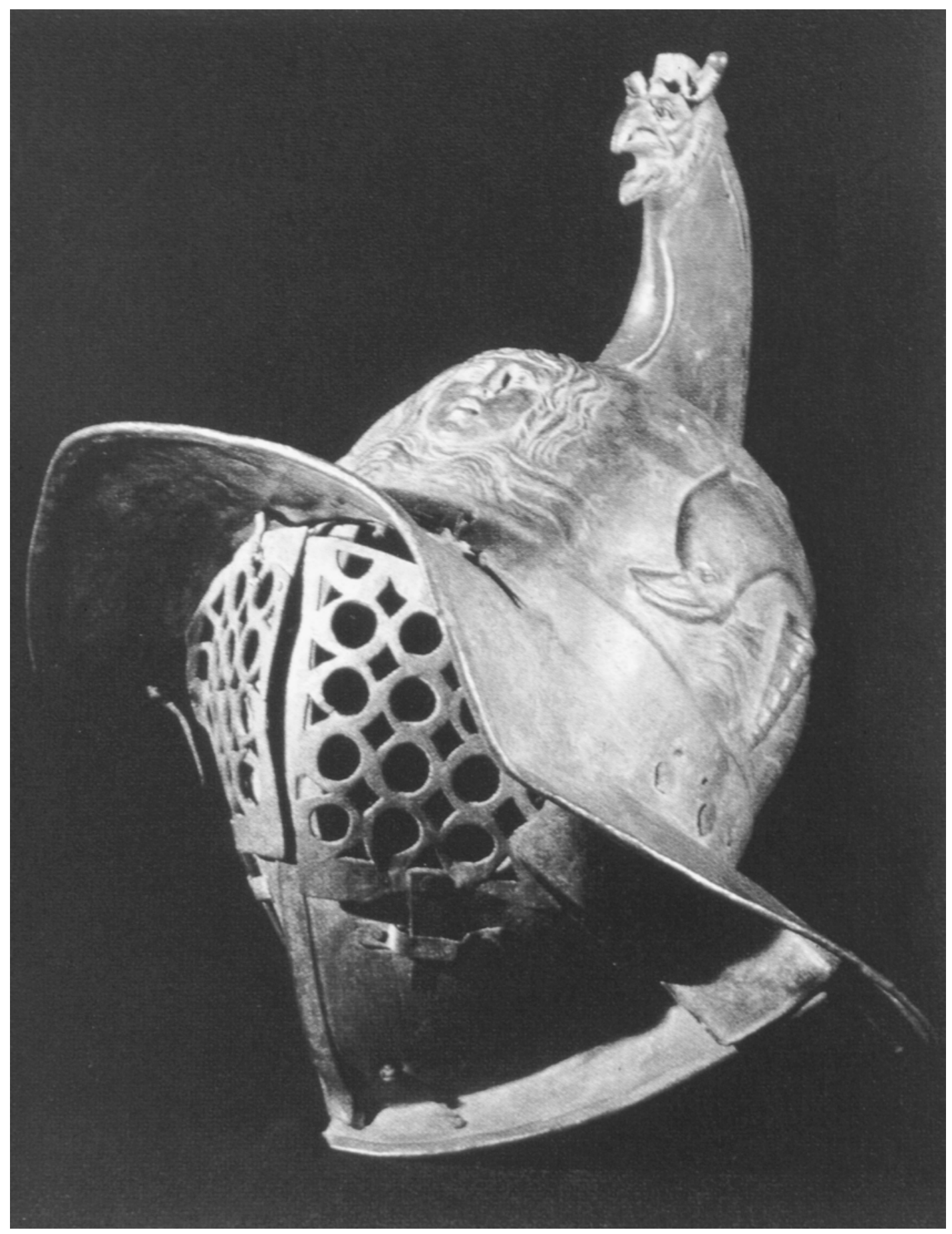

Fig. 2. Casco de Gladiador. Nápoles. Museo Nacional. 
verdaderas obras maestras del arte para las que, no debe olvidarse, dieron modelos iconográficos artistas de la talla de Andrea Mantegna o Alberto Durero ${ }^{14}$.

Si bien el siglo XV había supuesto el desarrollo total de la armadura con función defensiva, en la centuria siguiente ésta adquirió carácter suntuario y deportivo. Fue a partir del 1500 cuando se empezaron a difundir las decoraciones en las armaduras que consistían, primeramente, en la aplicación de toscos grabados realizados al aguafuerte. Sin embargo, en poco más de veinticinco años, se produjo una auténtica revolución decorativa en el trabajo de los armeros, quienes dotaron a sus piezas del carácter suntuario que la época reclamaba. Ello fue, en parte, una consecuencia de la obra literaria de Maximiliano I (1459-1519), en la que se reglamentaban todos los asuntos referentes a torneos y exhibiciones. Maximiliano, el promotor de la nueva moda, dio nombre al tipo de armaduras acanaladas, «a la maximiliana», que se difundirían en las restantes cortes europeas. Este emperador, que no en vano ha sido calificado como «el último caballero» intentó recuperar los ideales de caballería que estaban atravesando por un período de franca decadencia a finales del siglo $\mathrm{XV}^{15}$.

Es bien sabido que hacia 1525 ya se habían perfilado en Europa dos modos distintos de entender la decoración de la armadura que quedaron plasmados en las producciones de la corte de Augsburgo y las del milanesado. El equipo de armamenteo italiano se caracterizaba, a grandes rasgos, por los repujados en medio o altorrelieve para las figuraciones, combinadas con ataujías de plata y oro para las decoraciones vegetales, mientras que en las producciones salidas de los obradores alemanes predominaban los grabados al aguafuerte, aplicados sobre bandas doradas. En ambos casos, la manufactura de las armaduras requería un complicado proceso de fabricación y el conocimiento de una técnica metalúrgica altamente desarrollada. Las armaduras de fabricación italiana presentan, por su decoración y estilo, una relación muy estrecha con las artes plásticas, especialmente con los modelos escultóricos.

A la tradicional armadura heroica, cuyo propósito era eminentemente transfigurador, se sumó la creación de una armadura cubierta de festones y de figuraciones clásicas insertas en nichos, iconografía que tiene su origen en Giulio Romano, gran difusor de la decoración de tipo rafaelesco. Tales armaduras tuvieron un gran éxito en las cortes europeas, fundamentalmente en Italia, donde destacan las cortes de Urbino y de Mantua.

\section{LA PERCEPCIÓN DE LA MITOLOGÍA Y EL ARTE DEL RENACIMIENTO}

Cuando los humanistas florentinos del siglo XV hicieron suya la afirmación del filósofo griego Protágoras que pone al hombre en el centro del Universo, como medida de todas las cosas, ese hombre renovado, el humanista, estaría llamado a protagonizar la era moderna que se iniciaba en Europa. Sin embargo, según ha señalado Jean Seznec ${ }^{16}$ los los conocimientos sobre mitología del Renacimiento fueron, en general, más frágiles de lo que pudiera pensarse a priori. El citado autor defiende la idea de que eruditos y humanistas se conformaron, en general, con la información de segunda mano proporcionada por manuales o diccionarios mitológicos contemporáneos a ellos, obras deudoras en todo de la herencia de época medieval, siendo la Genealogia Deorum de Bocaccio el principal nexo de unión entre la mitografía de la Edad Media y la del Renacimiento; en la mayoría de los casos, las fuentes literiarias de inspiración no fueron las antiguas.

14 Un dibujo de este artista, en la Morgan Library muestra un diseño para el arnés, sobre el que Koloman Colman realizó una armadura para Maximiliano I, en 1517. Cfr. VVAA., Historical Armor, A picture book, Nueva York, 1951.

15 Para una perspectiva del mundo caballeresco véase VVAA., Tournaments and the dream of the Chivalry, Estocolmo, Armería Real, 1992.

16 Cfr. SEZNEC; J., Los dioses de la Antigüedad en la Edad Media y el Renacimiento (versión castellana de Juan Aranzadi), Madrid, 1987, p. 185 y ss. 
Llegado el siglo XVI, la imprenta fue un instrumento de divulgación de numerosas obras de carácter mitológico, pero tan importante instrumento sirvió al tiempo para publicar obras de la Antigüedad y obras de la Edad Media, hecho que no clarificó el estado de la cuestión. Se editaron el Comentario a Servio, Fulgencio, las Alegorías Homéricas de Palaephatus, los Tratados de Heráclito y Phornutus (1505), Macrobio $(1535,1541,1542)$, la Biblioteca de Apolodoro (1555), obras junto a las cuales tuvieron cabida reediciones de Marziano Capella, las Imagines Deorum de Albricus, el Libellus de Imaginibus Deorum, etc. En ocasiones, muchas de estas obras se reunieron en Antologías, confusas y de información desigual, razón por la que se hacía necesaria la aparición de una sistematización del saber mitológico.

Se sucedieron bastantes intentos para conseguir tal fin ${ }^{17}$, pero sólo a finales del siglo XVI comenzó a perfilarse una atrayente transformación en el análisis y la explicación de los mitos, cuyo origen debe buscarse en el impulso dado por la Reforma a los estudios bíblicos. Fue entonces cuando se sentaron las bases de una incipiente mitología comparada que habría de dar sus frutos, ya en la centuria siguiente, con los trabajos de Huet, Bochart y Vossius. La brillante exposición de Jean Seznec, cuyas ideas generales hemos recordado en estas líneas, no deja de ser una inquietante sorpresa. Y es que el mismo autor señala, para concluir, que es imposible salvar la distancia histórica que separó el Renacimiento de la Antigüedad, a pesar del esfuerzo consciente por armonizar dos universos separados. El Renacimiento supuso, en definitiva, la búsqueda de un reino imaginario, serena Arcadia en la que el gran corazón infeliz del hombre moderno busca asilo entre los dioses ${ }^{18}$.

Mientras se iba fraguando en Europa, durante el siglo XVI, lo que podría calificarse como «ciencia mitológica», los artistas supieron, con anterioridad, encontrar el acento justo para expresar el espíritu de la Antigüedad pagana en sus obras. Sus conocimientos sobre mitología no debieron de ser muy elevados, habida cuenta del panorama ideológico que acabamos de esbozar, y sin embargo, sus obras, acaso inspiradas en el legado arqueológico conocido ${ }^{19}$, fueron dignas émulas del arte antiguo. Quizás ello obedezca a que, como indicó Kenneth Clark, el pensamiento más profundo del Renacimiento no se expresó en palabras,

17 Entre dichos intentos destacan el Diccionario de Robert Etienne (París, 1512), los libros de Exempla, el De cognominibus deorum de Montefalco, etc. El modelo para la mayoría de ellos fue la Officina partim historicis partim poeticis referta disciplinis de Ravisius Textor, publicada en Basilea en 1503, obra ingente en la que se puede encontrar gran cantidad de información sobre el origen, filiación de los dioses, las fiestas a ellos dedicadas, etc. Más tarde, en 1532, Georg Pictor con su Theologia mythologica, renovaba la labor realizada un siglo antes por Bocaccio. Entre 1551 y 1556 aparecieron tres manuales de mitología italianos, cuya influencia habría de ser decisiva en los artistas: La Historia de los Dioses de Lilio Gregorio Gyraldi (Basilea, 1551), La mitologia de Natale Conti (Venecia, 1551) y Las imágenes de los dioses, de Vicenzo Cartari (Venecia, 1556). Las citadas obras tuvieron gran éxito en Europa, pero su método de trabajo y la explicación de los asuntos en ellas referidos seguía siendo medieval. El éxito de los tres manuales citados fue exorbitante y sus ediciones se repitieron constantemente, de modo que llegaron a figurar en la mayoría de las bibliotecas de pensadores, nobles y artistas, y, por ende, de cualquier hombre que se considerase cultivado. La literatura y el arte italianos de la segunda mitad del siglo XVI fueron, sin duda, reflejo de esta victoria de la mitología. Además, los citados manuales se difundieron no sólo por toda Italia, sino también a través de Francia, Inglaterra, Alemania y España.

Un libro de Guglielmus Choulius, De la religión de los antiguos romanos, editado en 1556, ofrece un panorama más científico y unas ilustraciones muy hermosas que rebosan del espíritu pagano auténtico, noble y sin vulgarizaciones. Todas las figuras de dichas estampas, a parte de la majestuosidad y acento antiguo, están identificadas por sus atributos iconográficos pertinentes, hecho que demuestra la utilización, no sólo de la literatura antigua, sino también de las fuentes arqueológicas. El mismo autor trabajó también en un Tratado sobre las religiones antiguas que nunca llegó a ver publicado, y que según referencias del propio autor, constituía una labor más seria y más científica que la realizada por sus contemporáneos. En España, habría que esperar a finales del siglo XVI para asistir a la publicación de la Filosofía Secreta, de Juan Pérez de Moya (Madrid, 1585), Cfr. SEZNEC, J., op. cit., p. 190 y ss.

18 Cfr. SEZNEC, J., op. cit., p. 263.

19 En 1506 se descubrió el célebre Laoconte, oculto entre las ruinas de las Termas de Tito que, como es bien sabido, fueron edificadas sobre la Domus Aurea de Nerón. Con este motivo tan inexcusable, muchos artistas siguieron acudiendo a las grutas del Palacio de Nerón cuya decoración se convirtió en paradigma a imitar. 
sino en imágenes visuales ${ }^{20}$. En la segunda mitad del siglo XV los artistas hicieron un denodado esfuerzo para estudiar los monumentos de Roma y aprender, de primera mano, el vocabulario artístico de la Antigüedad; las fuentes arqueológicas fueron determinantes, desde los pequeños objetos (monedas, medallas, gemas), hasta los relieves de los sarcófagos (reutilizados ocasionalmente en la Edad Media) ${ }^{21}$.

La fórmula más adecuada para armonizar las representaciones mitológicas con las enseñanzas cristianas, tras el Concilio de Trento ${ }^{22}$, la única vía posible, fue utilizar, otra vez, la mitología con sentido alegórico. Los mitos fueron un antídoto moral de las representaciones, de la misma manera que lo hubieran sido habitualmente para los eclesiásticos y, por ende, para los artistas de la Edad Media. La alegoría convertía a las imágenes paganas y a las fábulas licenciosas, en pretextos para condenar vicios morales, o por el contrario, para ensalzar virtudes, hecho que determinaría que la difusión de las figuras simbólicas adquiriera un extraordinario desarrollo durante el siglo XVI. Además, la mitología entró a formar parte de los entretenimientos cortesanos, en paradas, diversiones mitológicas o máscaras, que constituyeron verdaderos jeroglíficos morales. Italia, Francia, Inglaterra o España se sumaron a esta nueva modalidad de «espectáculo» aúlico, cuya más singular y brillante exposición tendría lugar, ya en el siglo XVII, en la corte de Versalles durante el reinado de Luis XIV.

Los artistas del Renacimiento, en su aspiración de redescubrir el arte antiguo, quisieron vestir a los dioses de la gentilidad con sus viejas túnicas y les devolvieron sus antiguos atributos, intentando despojarles de los extraños postizos que la Edad Media les había propinado, lo que no siempre consiguieron. De esta suerte, el arte del Renacimiento, basándose en el arte de la Antigüedad y con la asunción de la herencia dada por el Medioevo, forjaría unas imágenes simbólicas, unos prototipos en cierto modo canónicos, en los que, desde entonces, se apoyaría la Historia del Arte de occidente. Dicho de otro modo, la iconografía de los temas mitológicos fue, en el siglo XVI, la base sobre la que se alzarían los futuros prototipos iconográficos del Barroco y del Neoclasicismo, e incluso, de algunos estilos artísticos posteriores. Lo que en ningún caso se puede pensar es que dichas imágenes fueran inmutables, y por ello, cada época, cada estilo artístico y cada hombre, dotó a sus creaciones con sus propios matices y con su personal fantasía.

\section{LOS GRABADORES COMO AGENTES DE DIFUSIÓN DE LOS MODELOS CLÁSICOS.}

Al iniciarse el siglo XVI, los grandes genios del arte hallaron el terreno lo suficientemente abonado como para que las figuras de los dioses paganos y las fábulas mitológicas, encontrasen el camino definitivo de su futura iconografía. Mantegna, Leonardo da Vinci, Durero, Rafael y otros, sentaron las bases artísticas de formas y símbolos con sus modélicas creaciones. Por otra parte, los manuscritos iluminados y los grabados, en madera y cobre, se convirtieron, desde el siglo XV, en agentes transmisores de la iconografía, tanto pagana como cristiana.

Andrea Mantegna (1431-1506), a quien Vasari atribuye la invención del grabado en cobre $^{23}$, fue uno de los artistas del primer Renacimiento que conoció, de forma más completa y directa, el legado de la Antigüedad clásica. Sabido es que había visitado Grecia, y que entre

20 Cfr. CLARK, K., Civilización I, Madrid, 1979, capítulo 4.

21 Cfr. PyHRR, S.W./GODOY, J.A., op. cit., p. 10.

22 La Iglesia, tras las sesiones del concilio de Trento, recomendó usar con precaución las figuras de los dioses de la gentilidad, pero, a pesar de ello, la mitología triunfó porque los eclesiásticos doctos la favorecieron y amaron en su calidad de humanistas. La mitología era algo que había que usar con precaución, pero los artistas, apremiados por los comitentes de las obras, no tuvieron elección a la hora de decantarse por sus asuntos.

23 Cfr. TIETZE-ConRAT, Andrea Mantegna. Le pitture, i disegni, le incisioni, Florencia-Londres, 1955. 
sus pertenencias poseía una extensa colección de antigüedades, hecho que habría de tener una influencia decisiva en sus obras. Su interpretación de la Antigüedad sigue ejerciendo, aún hoy, una peculiar fascinación en el espectador. Mantegna comenzó a grabar en el año 1465, quizás en contacto con Antonio Pollaiuolo (1431-1498) ${ }^{24}$, y sería esta actividad una faceta artística que no descuidaría hasta su muerte. Gracias a los grabados, muchos de sus cuadros adquirieron popularidad y su obra impresionaría a personalidades como Giulio Romano o al mismo Tiziano.

Entre sus grabados de tema mitológico, Mantegna se ocupó de los asuntos relacionados con la mitología marina y los dioses del mar. Muy significativos son, en este sentido, una pareja de grabados en cobre que forman el conjunto denominado la «Batalla de los dioses marinos» (Chasworth, colección del Duque de Devonshire) (fig. 3), asunto que se relaciona, según diversas opiniones, con los ictiófagos descritos por Diodoro Sículo en su Biblioteca, o con Luciano. En nuestra opinión, parece bastante probable que Mantegna, buen conocedor del arte clásico, se hubiera podido inspirar en algún frente de sarcófago romano, cuyos prototipos evocan el espíritu que late en las citadas obras. La mayoría de los autores sostienen que su fecha debe calcularse en torno a los años 1480-81, por lo que consideramos estas estampas como hitos muy significativos en la difusión en la iconografía de los seres de la mitología marina. Algunos autores han señalado que la escena representada podría estar en relación con los torneos ejercitados en el transcurso de las fiestas cortesanas del Renacimiento, con un sentido alegórico, haciendo alusión a la envidia, la lujuria y la discordia ${ }^{25}$. Sea como fuere, la popularidad de estas estampas fue grande y pronto habrían de tener eco en otras obras de $\operatorname{arte}^{26}$.

En la iconografía de la «Batalla de los dioses marinos» de Mantegna se inspiraron también muchos de los motivos utilizados en la decoración de las armaduras, sobre los que trataremos más adelante. Podría aventurarse que el autor estuviera en contacto con algún taller de fabricación de armaduras, acaso proporcionando diseños para la decoración de las mismas, dado el extraordinario detalle con el que perfila la indumentaria guerrera de muchos de los personajes que pueblan sus pinturas, muy en especial la de Palas en la obra titulada Atenea expulsa a los vicios del jardín de la virtud (Museo del Louvre), en cuya celada advertimos la presencia de uno de los ictiocentauros tomados de dicha estampa, y cuyo peto se orna profusamente con un magnífico gorgoneion enmarcado entre bellísimos motivos vegetales.

Las estampas citadas fueron copiadas por Alberto Durero (1471-1528), artista que en sus obras enriqueció la concepción volumétrica del grabador italiano, realizando un modelado basado en trazos curvilíneos, y ganchos violentos en forma de coma, que confieren una vibrante vitalidad a las formas ${ }^{27}$. Durero había conocido la obra de Mantegna a través de Jacobo Barbari ${ }^{28}$, y tal hallazgo le convertiría en el verdadero agente de unión entre las técnicas del norte y del sur ${ }^{29}$.

Otro de los grabadores pertenecientes a la escuela de Mantegna, Nicoletto Rosex da Modena (activo entre 1500 y 1512) sería uno de los responsables de la popularización en el norte de Italia de la decoración al grutesco, en relación con los repertorios dados en las Loggie

24 Cfr. CÁMARA MUÑoZ, A., Mantegna, Madrid, 1993, p. 102.

25 Cfr. LightBown, R., Mantegna, Milán, 1986, p. 241.

26 Resulta interesante constatar, por ejemplo, su inclusión en una réplica de las Imagines de Filóstrato, ricamente ilustrada por el taller florentino de los Attavanti, para la corte de Mathias Corvinus hacia 1488-1489 (Budapest, Biblioteca Corviniana). Cfr. BERKOviTs, I., Illuminated Manuscripts from the Library of Mathias Corvinus, Budapest, 1964, pl.XXIV.

27 Cfr.PANOFSKy, Vida y arte de Alberto Durero, Madrid, 1982, p. 58.

28 Entre los artistas grabadores que integran la escuela de Mantegna merecen citarse Nicoletto da Modena, Antonio da Brescia, Giulio Campagnolo, Girolamo Mocetto, Zoan Andrea o Roletta, además del ya citado Jacopo Barbari. Cfr. GonZÁleZ de ZÁrATe, J.M., Artistas grabadores en la Edad del Humanismo, Pamplona, 1999, p. 50 y ss.

29 Ibidem, p. 47. 


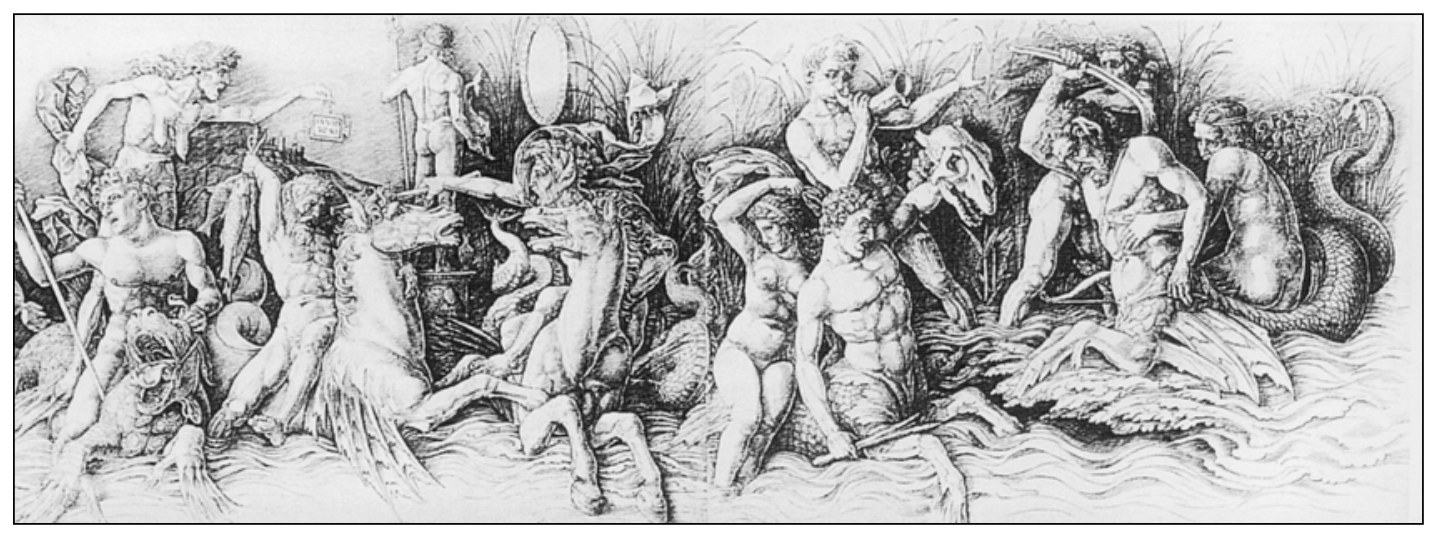

Fig. 3. Andrea Mantegna. Batalla de Dioses Marinos. Hacia 1470.

del Vaticano por de la escuela de Rafael, y popularizados por Antonio da Brescia y Agostino Veneziano. Estos motivos fueron recurrentes en la obra del artista de Módena, tras haber visitado Roma en 1507, momento en el que estuvo en contacto con Pinturrichio o Amico Aspertini. Se tiene constancia de que Nicoletto visitó las ruinas de la Domus Aurea de Nerón en aquella ocasión, lo que muy probablemente influyó en sus estampas, a partir de entonces convertidas en exponentes modélicos de una temática puramente ornamental. Tales estampas están plagadas de bichas, monstruos, grutescos y toda una serie de elementos figurativos fantásticos, sujetos a una sintáxis estructural y decorativa que entonces fue calificada de «romana» $\mathrm{o}$ «pagana», y cuyo máximo desarrollo se daría en los años centrales del siglo XVI ${ }^{30}$.

La escuela romana de grabadores se desarrolló, por su parte, tras los modelos dados por uno de los gigantes del Renacimiento clásico, Rafael Sanzio de Urbino (1483-1520), como ya se ha señalado. Fue el artista boloñés Marcantonio Raimondi (1480-1535) ${ }^{31}$ el principal difusor de la estética rafaelesca por Europa, mediante la actividad de un taller de grabado regentado por él, que abrió sus puertas en Roma en 1510, y al cual asistieron numerosos alumnos. Según Jean Adhémar ${ }^{32}$ la obra de Raimondi ofreció un amplio repertorio decorativo a los artistas del Renacimiento, definiendo, el ideal clásico de aquel tiempo, de acuerdo con los modelos rafaelescos.

Apenas han llegado hasta nuestros días unos pocos ejemplos de los «libros de patrones» utilizados por los armeros del siglo $\mathrm{XVI}^{33}$ para llevar a cabo la decoración de las armaduras. Destacan, en este sentido, los álbumes de Londres y Brunswick, únicos en su género ${ }^{34}$. De menor trascendencia es el álbum de diseños del pintor mantuano Filippo Orsoni (Londres, Victoria and Albert Museum). Junto a las obras citadas merece señalarse el repertorio de grabados en madera conocido como Ein Frembds und wunderbars Kunstbuechlein, de Heinrich Vogther el Viejo (1490-1556), publicado en Estrasburgo en 1538, y reeditado hasta siete veces en Alemania, Francia y España con anterioridad a 1556. Esta recopilación, ricamente ilustrada con cientos de grabados, es un compendio representativo de los motivos ornamentales más utilizados en el Renacimiento, entre los que se incluyen los de armas y armaduras.

30 Cfr.GONZÁleZ de ZÁRATE, J.M., op. cit., p. 51.

31 Delaborde, H., Marc-Antoine Raimondi, París, 1887.

32 ADHÉmAR, J., Les estampes, París, 1973.

33 Son conocidos, en cambio, algunos libros de patrones a partir del siglo XVII. Cfr. VVAA., Studies in european Arms and Armor. The C. Otto von Kiensbusch Collection in the Philadelphia Museum of Art. Simonin Pattern Books 1684-, Filadelfia, 1912.

34 Cfr. PyHRR, S.W./GODOY, J.A., op. cit., pp. 105-110. 
Era un libro destinado a los artistas en general, ya fueran éstos pintores, grabadores, orfebres, carpinteros, armeros o escultores ${ }^{35}$.

Todo parece indicar que éstos «muestrarios» responderían a los gustos propios del momento, y que a través de ellos, los comitentes harían sus encargos de acuerdo con sus preferencias, seleccionando los motivos más adecuados a cada ocasión ${ }^{36}$. Por sus diseños ornamentales, parece probable que estos modelos fueran tomados de los repertorios de grabados conocidos entonces, dadas analogías del lenguaje decorativo que presentan con ellos ${ }^{37}$. Algunas obras elaboradas en el siglo XIX se hacen eco de los diseños para las armas de los Reyes de Francia, Francisco I y Enrique II, dados por maestros alemanes ${ }^{38}$, lo que corrobora, también, la importancia concedida a los citados muestrarios.

\section{LA DECORACIÓN DE LAS ARMADURAS EN ÉPOCA DE CARLOS V}

Durante el reinado del emperador Carlos V los centros armeros italianos y alemanes ya estaban consolidados como los de mayor prestigo dentro del ámbito europeo. El monarca, siguiendo la moda impuesta por su abuelo paterno, que ejerció una influencia determinante sobre él, forjó su propia imagen a través de unas divisas iconográficas que pueden contemplarse en sus retratos, en los edificios para él construidos, y en las suntuosas armaduras que mandó realizar para exhibición y torneo. Los talleres alemanes y los italianos fueron, indistintamente, artífices de la realización de tales armaduras, que constituyen, sin duda, alguna, botín de excepción entre las obras de arte de su reinado. En la Real Armería destacan como el conjunto de mayor valor dentro de la colección y uno de los más homogéneos e importantes relativos al Renacimiento alemán, y en menor medida al italiano ${ }^{39}$.

La esmerada educación de Carlos V le había convertido en un caballero a la antigua usanza, según el código medieval de conducta; sin embargo, los ideales surgidos con el Renacimiento le hicieron, asimismo, conocedor de la Antigüedad clásica, de sus mitos y leyendas, asuntos que explotaría, a la postre, como emblemas representativos de su poder. El emperador halló en los exempla, ya fueran estos cristianos o de naturaleza pagana, medios para simbolizar su propia imagen, y la mejor expresión plástica de las virtudes que debían poseer los príncipes en aquel tiempo. Esta utilización de carácter moralista de la temática mitológica arranca de la tradición literaria desde el siglo III a. C., y dio lugar a toda una usanza ejemplarizante de las leyendas antiguas, que llegó al Renacimiento, como ya hemos apuntado, a través del mundo medieval, siendo las Etimologías de Isidoro de Sevilla uno de sus vehículos más importantes de transmisión.

Checa Cremades ${ }^{40}$ ha reseñado que la vinculación del Carlos V a la Antigüedad se verificó de dos formas distintas: como emulación y superación, por un lado, y a través del ejemplo que ofrecen los héroes antiguos, por otro. En el siglo XVI, reyes y nobles impusieron la moda de asimilar su propia imagen a la de los héroes y dioses de la mitología clásica, hecho que tuvo sus principales manifestaciones en el campo de la fabricación de armas y armaduras ${ }^{4 l}$. La armadura proporcionaba un disfraz antiquizante que, por sí misma, servía para equiparar

35 Cfr. PyHrR, S.W./Godoy, J.A., op. cit., n.14.

36 Cfr. Fliegel, S..N., Arms and Armor, The Cleveland Museum of Art, Nueva York, 1998 y Fidelis BuTSCH, A., Handbook of Renaissance ornaments, Nueva York, 1969.

37 Cfr. JEAN-RichaRD, Ornemanistes du XVe au XVIIe siécle. Gravures et dessins, París, 1987.

38 Cfr. BeDAT, D., Dessins originaux de maitres allemands por armures de luxe destinés a des Rois de France, Munich (s/a).

39 Cfr. Soler, A., Soler Del CAmpo, Á., Guía. Real Armería. Palacio Real, Madrid, Patrimonio Nacional, 2000, p. 40.

${ }^{40}$ Cfr. CheCa Cremades, F., Carlos V. La imagen de poder en el Renacimiento, Madrid.

41 Ibidem., p. 199. 
a los príncipes con los antiguos héroes legendarios. Esta ficción que convertía al monarca en restaurador de la antigua gloria de Roma, se intensificó desde 1530, tras el viaje triunfal de Carlos V por Italia, transformándose en auténtico mito con el que expresar la imagen de su extraordinario poder. La virtud heroica fue, en muchos casos, un medio para proyectar ante el mundo las hazañas reales y, en definitiva, la propaganda política necesaria para controlar un inmenso imperio.

Por otra parte, el vasto dominio territorial de Carlos V y su control militar, tanto marítimo como terrestre, le hicieron merecedor del favor de los dioses, Neptuno y la Tierra, muy en especial. Tampoco podemos olvidar la bien conocida importancia de la capacidad marítima de su reinado, tiempo de descubrimientos en que la hegemonía del poder naval resultaba esencial en la defensa de un Imperio ${ }^{42}$. En el trabajo que nos ocupa, esta dimensión marítima es la que justifica, en una muy significativa medida, la utilización de motivos decorativos marinos en las armaduras, aunque, como veremos, siempre unida a razones de diversa índole.

La potencia marítima del imperio de Carlos V quedó simbolizada en la llamada Rodela del Plus Ultra (D-63) (fig. 4), obra realizada en el norte de Italia en los años centrales del siglo XVI, cuya soberbia decoración, basada en un dibujo de Giulio Romano del Teylers Museum (Harlem) ${ }^{43}$ muestra el tema de la «Apoteósis de Carlos V», para quien fue realizada. El emperador, ataviado como un César romano, se yergue altivo sobre un birreme, precedido por la personificación de la Fama, y seguido por una Victoria alada que le concede la corona laureada como claro signo de su triunfo. El poderoso Hércules transporta sus columnas desde los límites antiguos (Gibraltar) hasta más allá de éstos, es decir, hasta África, mientras el soberano del mar, Neptuno ${ }^{44}$, cede parte de su potestad al emperador, ayudando con su mano - que empuja una de las columnas - a que se amplíen los dominios marítimos de éste. En la zona inferior de la composición aparecen representados una hermosa personificación del misterioso Océano Atlántico (o el río Betis, según han señalado algunos autores), que se recuesta majestuoso con un cántaro manante y un cuerno repleto de frutos en sus manos ${ }^{45}$, y una personificación femenina de África, el nuevo continente sometido por Carlos $\mathrm{V}^{46}$.

Acaso el motivo que mejor caracteriza la iconografía marina del período que nos ocupa sea el delfín, cuya reiterada presencia, ocupando los campos decorativos más diversos, llama poderosamente la atención. El delfín (delphinus delphis) es un animal fuerte, veloz, hermoso, inteligente, brillante, un ser cuya sola efigie irradia ritmo armonía y gracia, razones que consideramos suficientes para que fuera un animal predilecto por los artistas desde la Antiguiedad. Si a ello sumamos que el delfín es un animal colmado de virtudes, fiel amigo del hombre y de sus congéneres, no es de extrañar que todas las culturas mediterráneas cuya soberanía se

42 Cfr. Carlos V. La naútica y la navegación, (Exposición, Museo de Pontevedra, septiembre-diciembre 2000), Ministerio de Cultura, 2000.

43 Cfr. Checa Cremades, F., Carlos V y la imagen del héroe en el Renacimiento, Madrid, 1987, pp. 201 y ss.

44 Como ha señalado Checa Cremades, Hércules y Neptuno vinieron a simbolizar el doble contenido de las victorias imperiales. Ibidem, p. 112.

45 Uno de los prototipos iconográficos utilizados para representar a Océano, desde época romana, es una figura masculina barbada que se recuesta sobre un cántaro manante alusivo a su caudal y que, habitualmente ostenta un cuerno de la abundancia alusivo a su naturaleza fertilizadora. Idéntico prototipo sirvió, desde entonces, para representar a todos sus hijos, los tres mil ríos de la Tierra, según la Teogonía de Hesíodo. Esta similitud se basó, fundamentalmente, en la creencia de que Océano era el río envolvente de la Tierra. Cfr. RODRíGUEZ LÓPEZ, M.I., «Océano. Iconografía de un dios abismal y misterioso», Revista de Arqueología, n.226, marzo, 2000.

46 La efigie utilizada en esta ocasión para personificar a África es una imagen maniatada, expresionista por su gesto, rodeada de las armas de las que había sido previamente despojada. El símbolo parlante deja ver, además, una palmera y un turbante colgado sobre ella, alusión clara al vencido imperio turco. La personificación de África como figura femenina fue asunto característico de la iconografía romana, especialmente de los mosaicos tardíos, como ponen de manifiesto bellos ejemplares hallados en Piazza Armerina, en los que la figura ostenta cuerno de abundancia y está rodeada de animales propios del territorio al que representa. En el ejemplo que nos ocupa resulta completamente novedosa, desde el punto de vista iconográfico, la presencia del turbante al que nos hemos referido. 


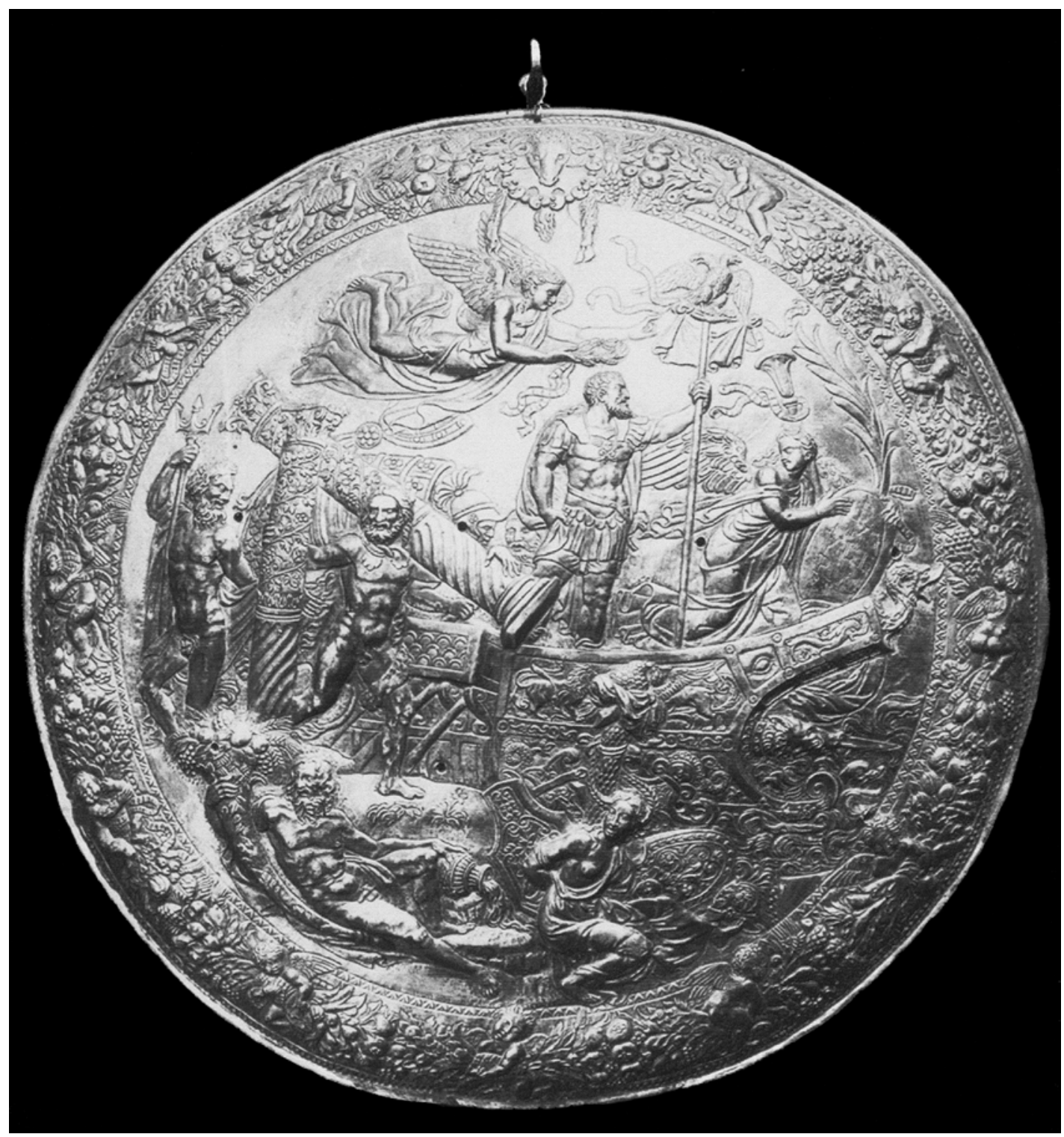

Fig. 4. Rodela. Real Armería, cat. D-63. Fotografía por J. Laurent, hacia 1870.

ha basado en el mar, hayan considerado al delfín como un símbolo y un emblema distintivo, y que le hayan otorgado el papel de imagen simbólica con la que materializar una serie de cualidades del príncipe, o con la que expresar la garantía de inmortalidad. Las leyendas de Arión, Melicerte, Taras y otros héroes de la mitología griega son ejemplos legendarios de la ancestral amistad entre hombres y delfines, referida, asimismo, en numerosas narraciones antiguas. Amable montura del ser humano, su salvador ante los peligros del mar, auxilio de naúfragos, el delfín fue, desde la Antigüedad, un ser querido por el hombre ${ }^{47}$.

47 Son muchos los relatos fabulosos que nos narran historias de salvaciones de humanos por delfines, y del amor y compañerimo entre ambas especies, relatos difundidos por varios autores y situados en diferentes zonas geográficas marítimas. De ellos destacamos los que incluye Claudio ELIANO en su Historia de los animales: «el delfín y el mucha- 
Los delfines fueron considerados por los navegantes egeos como símbolos de buenos augurios. El delfín era el pez-piloto, el amigo del hombre que le guiaba en sus travesías, por lo que, desde fechas muy tempranas, se le representaba sobre la quilla, para invocar con su icono a los compañeros vivos ${ }^{48}$. El conocido «fresco de la flota « de Akrotiri nos muestra, entre otras escenas, la habitual imagen de delfines que, con su salto, navegan por el Mediterráneo acompañando a los barcos, como si trataran de indicarles el camino más seguro.

Las criaturas marinas, en general, fueron consideradas como signos de inmortalidad y acaso por ello, su presencia en las tumbas del tercer milenio antes de Cristo, especialmente en el ámbito cretomicénico, fuera tan abundante. Sería razonable pensar que el mar o el elemento líquido jugaran un papel predominante en las creencias sobre la vida futura, a la que se llegaba a través de un viaje por agua (o mar), considerado como un pasaje simbólico desde los más remotos tiempos. Más tarde, las creencias religiosas de los pueblos mediterráneos tenderían a situar las Islas de los Bienaventurados, los Campos Elíseos, en un lugar situado allende el Océano. El agua como fons et origo no puede desligarse de las creencias religiosas y de la idea de retorno al origen, tras la muerte, asociada a la inmortalidad. La raíz griega de la palabra delfín (delphys) está en relación con la voz griega utilizada para designar al útero o matriz, con el origen de la vida y con la fuente húmeda de la que todo surge, según el principio del filósofo presocrático Tales de Mileto. Merece señalarse también que el delfín cedió su nombre al más importante oráculo del Mediterráneo antiguo, Delfos, santuario de Apolo, considerado delphinios, según algunas tradiciones mitográficas ${ }^{49}$.

Los griegos, forjadores de mitos para la eternidad y de imágenes geniales para expresar plásticamente tales leyendas, convirtieron al delfín en uno de los atributos iconográficos de Poseidón, el dios soberano del mediterráneo. El delfín pasó a ser, también, rey de los peces, y desde entonces es conocida su vinculación simbólica con la realeza. Ya en el Palacio de Cnoso, su silueta adorna las habitaciones reales, y estaría llamado a ser, más tarde, emblema de la soberanía marítima de las naciones. El heredero del trono francés tenía que haber ostentado, previamente, el título de Delfín de Francia, primera dignidad honorífica después del rey.

Cuando finalizaba el siglo II d. C., en Roma, la filosofía cristiana adoptó el delfín para convertirlo en un símbolo parlante de sus propias ideas, y lo consideró como metáfora y alegoría de Cristo Salvador y de la Eucaristía, aspecto que conviene a la idea de salvación eterna. Pez crístico, el delfín auxilia y es señal simbólica de la transmigración de las almas hasta el más allá. En la imaginación cristiana, también fue percibido como figuración de Cristo combatiente, como Cristo triunfante ${ }^{50}$, aspectos todos ellos que hacen muy apropiada su representación en la decoración de las armaduras ¿qué mejor protección para un guerrero o justador que una imagen avalada por una tradición simbólica tan dilatada?. Por todo lo expuesto, no es extraño que Carlos $\mathrm{V}$, eligiera la imagen del delfín como uno de los más elocuentes símbolos representativos de su soberanía. En el delfín, como hemos podido verificar en las líneas precedentes, afloraban muchas ideas antiguas, y su imagen era una prueba más del sincretismo pagano-cristiano utilizado por el emperador, al que ya nos hemos referido. El delfín era imagen del rey y símbolo de Cristo, salvaguarda y protector del hombre, y garante de la inmortalidad en caso de muerte.

cho de Jaso», «El delfín capturado», «Historia de la amistad entre un delfín y un muchacho de la isla de Proselene», etc. Cfr. Eliano, C., Historia de los animales (edición a cargo de José María Díaz-Regañón López), Madrid, 1984, I, V, 18; II, 6,8,52; V, 6,48; VI, 15; VIII 3,11.

48 VVAA., Greece and the Sea, Amsterdam, 1987.

49 Apolo es un dios que personifica, entre otros muchos y variados aspectos, los diversos estados de las sociedades nacientes: cazador(agraiyus), pastor (nomios, karneios), guía de los caminos (agyieus), y colonizador (delphinius). Cfr. «Apolo», en DAREMBERG-SAGLIO, Ch., Dictionnaire des Antiquités grecques et romaines, Viena, 1967.

50 Cfr. IERARDO, E., El agua y el sonido, el salto y el delfin, http://www.temakel.com/simbolodelfin.htm 


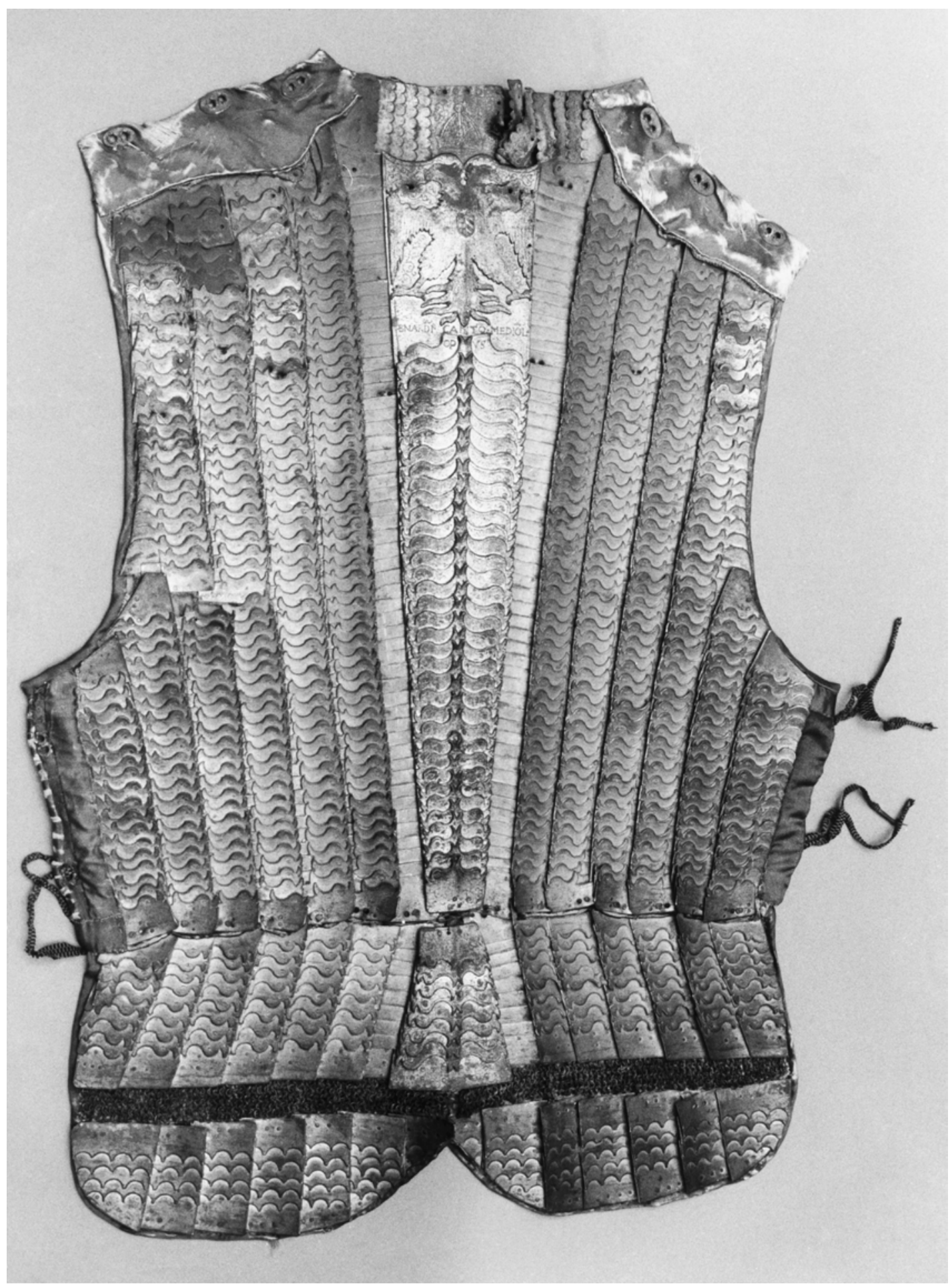

Fig. 5. Coracina. Real Armería, cat. C-11. 
Desde el punto de vista plástico, la forma sinuosa y pura del perfil de los delfines ofrecía numerosas posibilidades a los artistas, como veremos, ya que se adapta con extrema facilidad a cualquier marco decorativo y con ella pueden subrayarse la más perfecta simetría, la cuadratura o, las más atrevidas soluciones compositivas. Dicha forma, con toda la gama de incurvaciones a que puede ser sometida se presta, también, a la fantasía más extraordinaria, lo cual resulta muy apropiado a los repertorios decorativos en voga por aquel entonces, siendo frecuentes las imágenes caprichosas e hibridadas en las que se aunaban motivos acuáticos y vegetales, en un todo exhuberante y curvilíneo. Por otra parte, el brillante destello de la piel húmeda del delfín es similar al luminiscente esplendor que ofrece la superficie de una armadura regia. Si su tersa piel adquiere escamas en las obras de arte es, quizás, para que dicho fulgor resulte atractivo en su irradiación, al producir contrastes lumínicos.

La coracina de Bernardino Cantoni ${ }^{51}$, seguramente realizada para Maximiliano I y heredada por Carlos V es una obra singular (C.11) (fig. 5) en la que la iconografía del delfín se despliega de un modo sutil ${ }^{52}$. La integran numerosas launas, fijadas a un soporte textil. Cada una de ellas tiene forma de diminuto delfín esquematizado, y los ojos de todos y cada uno de estos animales marinos han sido pintados en rojo. Es de señalar lo ingenioso del diseño de la obra, en la que la banda central (adornada con el águila bicéfala) constituye un poderoso eje de simetría en torno al cual han sido dispuestos, a ambos lados, los citados delfines, afrontados entre sí por la dirección opuesta de sus cabezas. En las cuatro últimas hileras del faldaje las launas se tornan convexas y continuas, acaso para simular, de forma convencional, las ondas marinas y completar con agudeza este fino diseño.

Analizando las piezas de la época que tratamos, nos resulta sugerente la idea de que el mismo perfil de algunas borgoñotas, con su contorno superior abombado, y su pronunciada visera pudieran haber sido concebidas por los «diseñadores» de armaduras partiendo de la idea de mímesis con la cabeza del hermoso mamífero marino Esta idea se advierte con nitidez en la borgoñota realizada para el emperador, hacia 1530, por el armero imperial de Augsburgo(A. 59) ${ }^{53}$, pieza extraordinaria en muchos aspectos (fig. 6). Desde el punto de vista iconográfico puede observarse en ella una deliciosa asimilación de formas, cuyo propósito debió de ser eminentemente transfigurador. El supuesto delfín posee ojos casi humanos, que adquieren toda su expresividad en la visión frontal, semejando el brillo de su acero repujado a la técnica de la incrustación de pasta vítrea. Sobre las sienes, un remate avolutado y dorado que se incurva hacia arriba a modo de cresta (o aleta dorsal), da paso a un cuerpo escamado que, disminuyendo de proporción anatómica, se bifurca en dos colas pisciformes, también provistas de escamas, para ocupar por completo el marco compositivo, de acuerdo con un esquema simétrico ${ }^{54}$.

Técnicamente, la pieza presenta trabajo de repujado, grabado, y ataujía de oro, estando imbricados entre sí todos y cada uno de sus elementos, ya sean éstos formales, decorativos o funcionales; el resultado es una obra maestra ${ }^{55}$.

51 Cfr. Soler Del CAMPO, A., op. cit., pp. 35-36.

52 Para las referencias catalográficas de la Real Armería véase, VALENCIA DE DON JUAN (Crooke y Navarrot, Juan Bautista), Catálogo histórico-descriptivo de la Real Armería, de Madrid, Madrid, 1898.

53 Cfr. Felipe II. Un monarca y su época. Un príncipe del Renacimiento, Museo del Prado, 1998, n.72.

54 Una pintura sobre pergamino perteneciente a una de las ilustraciones de Romulus, de 1480 (Biblioteca Apostólica Vaticana, Cod. Urb. Lat. 899, folio 74 r) presenta al hijo de Marte y legendario fundador de Roma con una borgoñota que serviría de inspiración para los armeros de Carlos V a la hora de elaborar la pieza que tratamos. Cfr. PYHRR, S.W./Godoy, J.A., op. cit., n.26.

55 Otra hermosa pieza realizada en acero, oro y plata, perteneciente a la colección del Museo Metropolitano de Nueva York presenta todo su contorno escamado, como si se tratara de simular, también, la imagen de un delfín o pez. Es trabajo típico del taller milanés regentado por los Negroli. Cfr. PYHRR, S. W., European helmets, 1450-1650. Treasures from the Reserve Collection. The Metropolitan Museum of Art, Nueva York, 2000, n.31. 


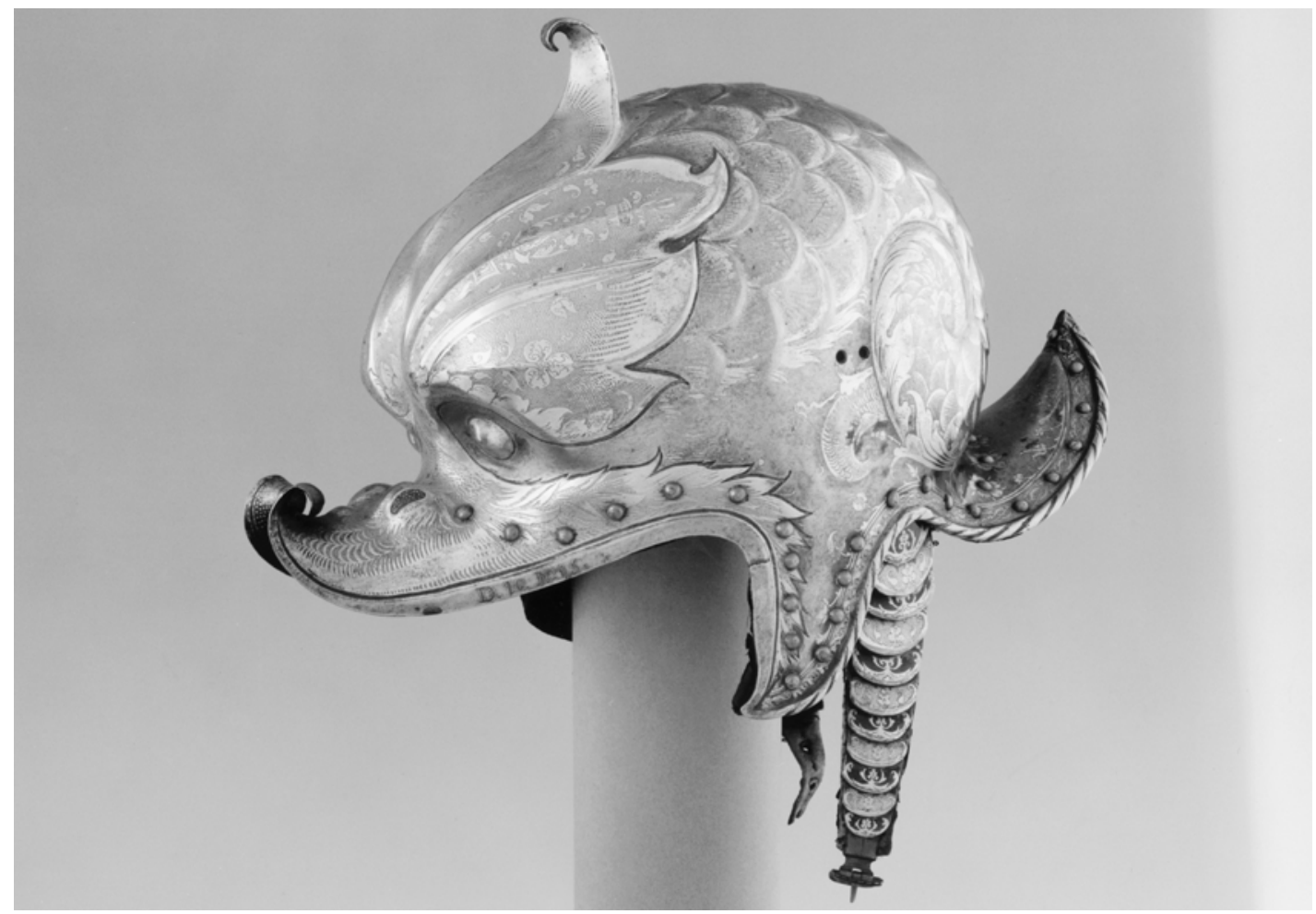

Fig. 6. Borgoñota. Real Armería, cat. A-59.

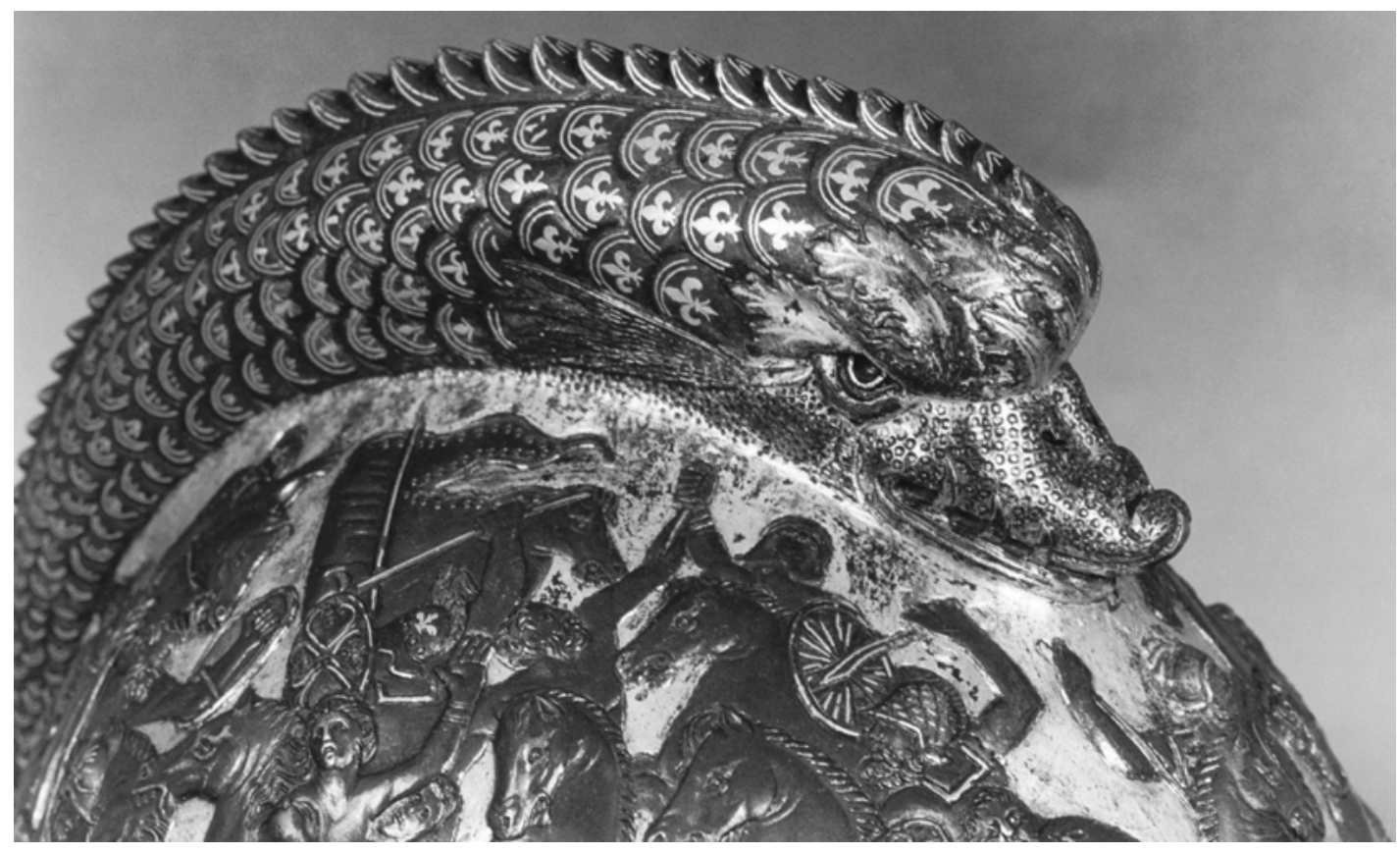

Fig. 7. Borgoñota. Real Armería, cat. M-5. 
La misma idea decorativa y compositiva puede apreciarse en una celada que forma parte de las denominadas guarniciones del KD (Karolus Divus) (A.29) en la que una cabeza de delfín realizada en acero dorado, a modo de relieve, ocupa el lugar central de la pieza, sobre la visera. De ella surgen, incisas, hacia ambos lados, las siluetas del cuerpo de dos delfines. También en este caso se pone ante nuestros ojos una finísima labor técnica, y una no menos ingeniosa solución iconográfica con la que abordar un campo decorativo de forma esférica, capaz de acrecentar la sensación volumétrica de los elementos representados. Además, la bicromía resultante de la combinación entre el acero dorado y el plateado, resulta, también en este caso, muy atractiva.

La celada de la armadura de Carlos V llamada «de Argel» (A.154) está decorada con delfines, cuyas cabezas ocupan la parte superior de la pieza (acero dorado) mientras que sus hermosas y curvilíneas extremidades, plagadas de escamas en las que se detiene sutilmente la luz, se disponen ocupando la parte posterior del conjunto; es una hermosa pieza provista de rejilla en el frente, cuya cabeza se cubre con una extraordinaria figuración. Un grifo ocupa el espacio frontal delantero, mientras que otro monstruo cornudo y de hocico alargado puede verse en la parte posterior del conjunto, y, como ya hemos señalado, dos delfines se sitúan en los laterales del mismo. Las cabezas y arranque de los cuerpos de éstos forman parte de la pieza superior (la misma en la que se encuentran los dos monstruos citados), de acero dorado, pero sus extremidades han sido realizadas, con todo detalle, sobre la nuca de la celada propiamente dicha, en acero en su color.

La borgoñota M.5 (fig. 7), obra de factura italiana y fechable en torno a 1540-1550, posee una exhuberante y abigarrada decoración protagonizada por escenas de batalla. Su cresta, con esmerada labor de pavonado, pone ante nuestros ojos la figura de un delfín cuya silueta se adhiere, incurvándose, a la pieza ${ }^{56}$. En esta ocasión, se trata de una figura de cabeza algo terrorífica, amenazadora, cuyo lomo presenta un perfil dentado en toda su longitud, y cuyas escamas han sido detalladas una a una; en el interior de las mismas puede apreciarse una insignia flordelisada en oro.

En ocasiones, las bardas presentan cabezas de delfines, a modo de máscaras, situadas en el guardamaslo (bardas A.149 y A.65), ubicación que refuerza la idea del delfín como imagen protectora y, acaso la que proporciona velocidad al caballo que la exhibe ${ }^{57}$.

También podemos señalar la presencia de los delfines como parte de la decoración de las sillas de montar. Es motivo principal de ornamentación en algunas obras, como por ejemplo, en la silla de fabricación alemana de autor anónimo, fechable en torno a 1535-4058 (F.44) en la que dos delfines repujados ocupan el arzón delantero, acomodados con sabiduría al campo decorativo que les corresponde. Sus imágenes se vuelven caprichosas en la incurvación excesiva de su hocico y las aletas (dorsales y pectorales), semejan foliaciones vegetales. Su cuerpo escamoso remata en cola sencilla, pero adornos tripétalos, análogos a los remates pisciformes utilizados en otras ocasiones, decoran la perilla. En otras ocasiones, los delfines que decoran las sillas forman parte de todo un complejo mundo de símbolos ornamentales, tal y como puede apreciarse en la silla correspondiente a la barda A.149, donde los delfines aparecen grabados, al lado de diversos instrumentos musicales ${ }^{59}$.

\footnotetext{
56 Modelos análogos a esta borgoñota pueden verse en los grabados sobre madera del Album Ein frembds und wunderbars kunstbuechlein, de Heinrich Vogtherr el Viejo, publicados, como ya se ha reseñado, en diversas ocasiones y en varias ciudades europeas, desde 1538. Cfr. p. 13

57 Una de las cualidades más sobresalientes del delfín común es su extraordinaria velocidad que puede alcanzar los $50 \mathrm{Kms}$./hora, lo que le convierte en el más rápido e inalcanzable de los cetáceos.

58 Por razones estilísticas, esta silla ha sido atribuida de Desiderius Helmschmid. Cfr. Carlos V. La náutica y la navegación, Museo de Pontevedra, ficha n.93.

59 Tal vez la asociación entre el delfín y la música pueda hallar su justificación mitológica en la leyenda del músico Arión, salvado por un delfín. Cfr. HERODOTO, I, 24.
} 


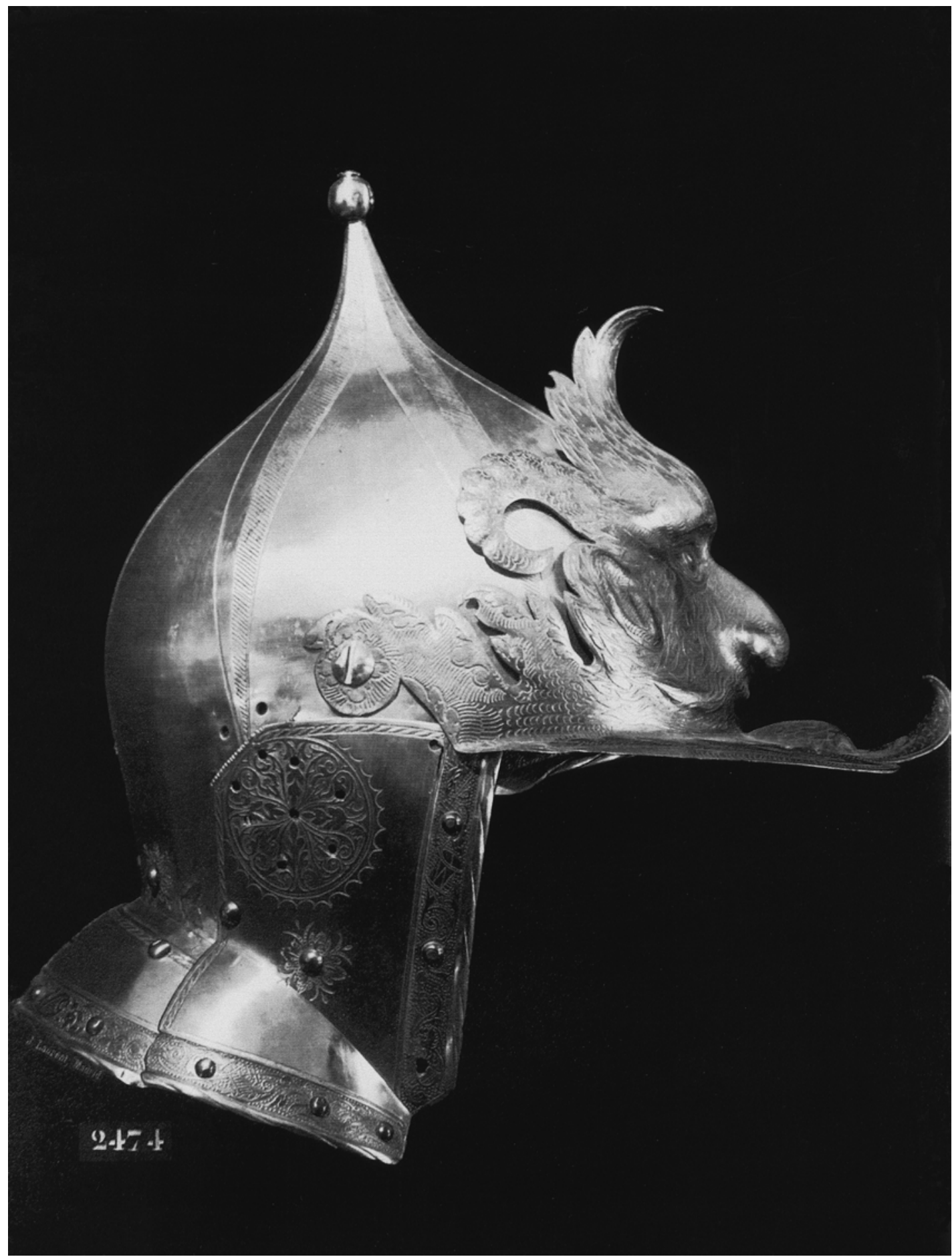

Fig. 8. Celada. Real Armería, cat. A-118. Fotografía por J. Laurent, hacia 1870. 
A todo lo expuesto habría que sumar la presencia de figuras o cabezas de delfines que, en numerosas obras del período que nos ocupa, están perfiladas entre los grutescos y otros motivos de decoración. Algunas de ellas pueden verse en obras tan tempranas como la celada A-38, donde las cabezas de delfines forman parte de un elaborado y convencional lenguaje decorativo inscrito por bandas. En el peto A.129, los dorados delfinidos forman parte de un conjunto decorativo junto a zancudas, mascarones y diversos motivos vegetales, mientras que en el peto italiano M.10, una pareja ocupa la parte inferior de un conjunto vegetal, y sus colas ascienden desde allí para confundirse con los roleos vegetales. Por su parte, el birrete D.29 realizado en el taller de Desiderius Helschmid, hacia 1540, presenta también decoración de delfines dorados como parte de un intrincado decorativo de grutescos.

Los seres marinos, imágenes más o menos monstruosas, pero siempre productos de la fantasía, y de difícil designación, fueron motivos recurrentes de decoración en la época que tratamos. Estas imágenes tienen sus antecedentes iconográficos en las representaciones de los míticos habitantes del Mediterráneo antiguo (Nereo, Tritón) o el desconocido y misterioso Océano Atlántico. Sus figuras, tal y como puede apreciarse en la celada A.118 (fig. 8) son el resultado de una extravagante simbiosis entre los mascarones con los que el arte de la Roma antigua representó a Océano, y la decoración al grutesco característica del arte del Renacimiento. La personificación del Atlántico, deidad primordial, fue un elemento iconográfico muy en voga durante el arte romano de época imperial, especialmente en obras de naturaleza decorativa, mosaicos en particular. Habitualmente se le representaba como una carátula o mascarón mostrando un personaje barbado, de avanzada edad, de cuyas guedejas brotaban plantas acuáticas, pinzas de crustáceos, e, incluso, pececillos (quizás como símbolos plásticos de su legendaria fecundidad), tipología que había nacido en el arte griego helenístico ${ }^{60}$.

La unión entre elementos marinos y vegetales, tal y como puede verificarse en los repertorios decorativos del arte renacentista, hunde sus raíces, en una medida muy significativa, en la iconografía de Océano que acabamos de describir. La pieza que nos ocupa participa del eclecticismo citado: en ella podemos contemplar un rostro marino, húmedo, plagado de plantas acuáticas, y provisto de cornamenta retorcida (iconografía característica de los sátiros y personajes asociados con el thíasos báquico $)^{61}$.

Las tritonisas o sirenas pisciformes, normalmente acompañadas de otros asuntos iconográficos, también formaron parte de los repertorios ornamentales utilizados por los arme$\operatorname{ros}^{62}$. El arzón trasero de la silla realizada por Kolman Helschmid (1517-1518) (A.150) (fig. 9) muestra, en su centro, a una sirena pisciforme repujada que sostiene con sus manos los dos extremos de su escamosa cola, siguiendo prototipos iconográficos habituales en el medioevo. Sus cabellos, largos y rizados, ondean al viento y han sido grabados con toda minuciosidad, probablemente atendiendo a las descripciones de estas criaturas marinas dadas por las fuentes literarias medievales ${ }^{63}$. Es una figura hierática, concebida frontalmente, que está

60 Cfr. RodrígueZ LÓPEZ, M.I., «Océano, iconografía de un dios abismal y misterioso», Revista de Arqueología, n.226, pp. 30-41.

61 El thíasos báquico o cortejo dionisíaco era el tropel de dioses encargados de celebrar las fiestas en honor de Dioniso. Lo integraban los sátiros, las ménades, los silenos y todas las criaturas salvajes a menudo entretenidas en actos de carácter orgiástico, como símbolos de la fecundidad de la tierra. El thíasos marino se formaría, en el siglo IV, por influencia del thíasos báquico, como trasunto de la fuerza sobrenatural, y también fecunda del mar. Las artes plásticas se sirvieron, en la Antigüedad, de motivos decorativos tomados de ambos cortejos, en ocasiones asociados entre sí. Cfr. RODRÍGUEZ LóPEZ, M.I., Posidón y el thíasos marino en el arte mediterráneo (desde sus orígenes hasta el siglo XVI), Tesis Doctoral, Madrid, UCM, 1993, CD- Rom, ISBN: 84-8466-130-X.

62 La figura de la sirena encierra en sí misma una combinación de belleza y terror, y precisamente esa idea sería uno de los factores que contribuyeron a que fuera motivo iconográfico predilecto, ya que impresionaría al enemigo. Cfr. NiCKEL, H., Arms \&Armor from the permanent collection. The Metropolitan Museum of Art, Nueva York, 1991.

63 Cfr. RodríGueZ LóPEZ, M.I., Posidón y el thíasos marino en el arte mediterráneo (desde sus orígenes hasta el siglo XVI), Tesis Doctoral, Madrid, UCM, 1993, CD- Rom, ISBN: 84-8466-130-X. pp. 380 y ss; pp. 479 y ss; pp. 929-931. 


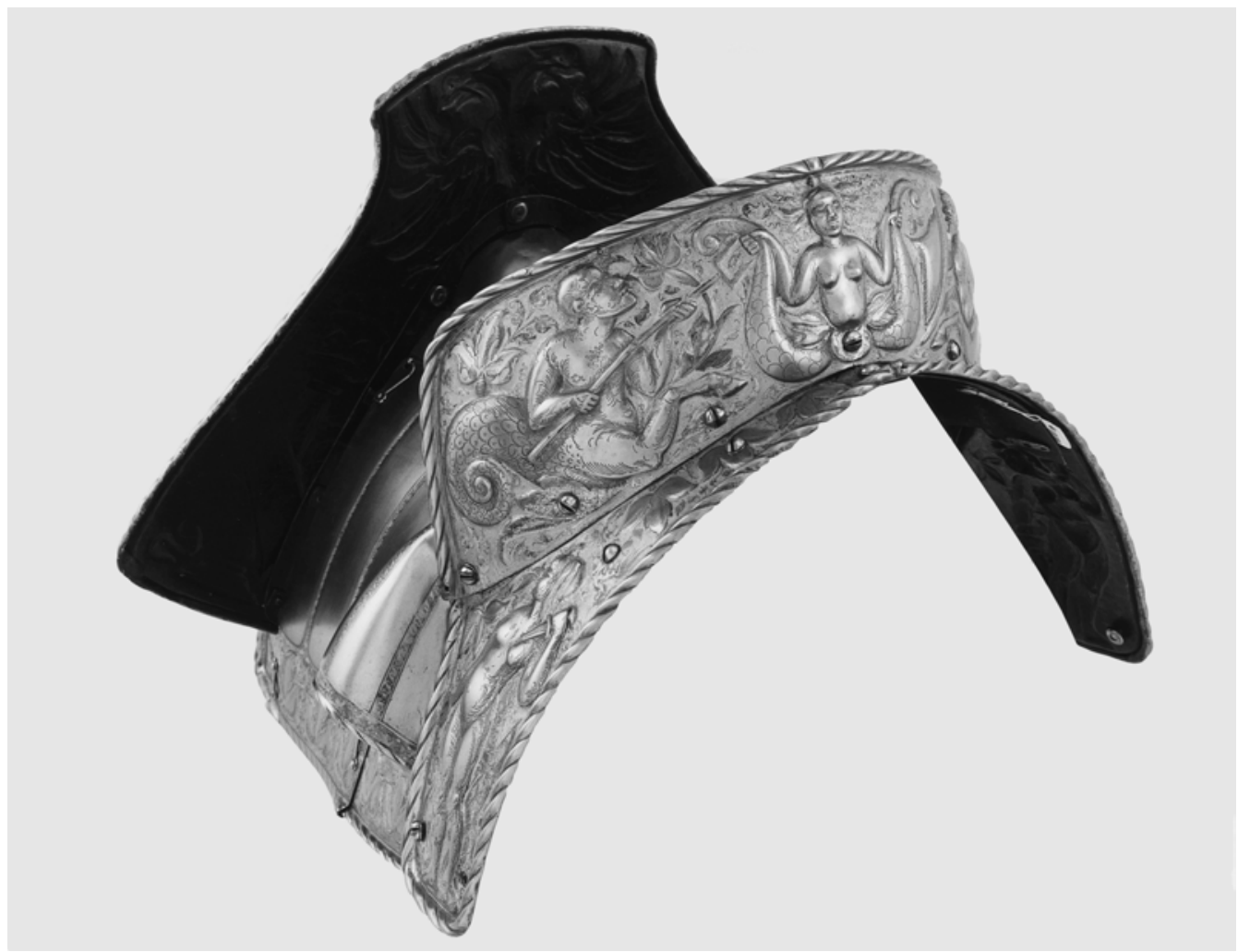

Fig. 9. Silla de montar. Real Armería, cat. A-150.

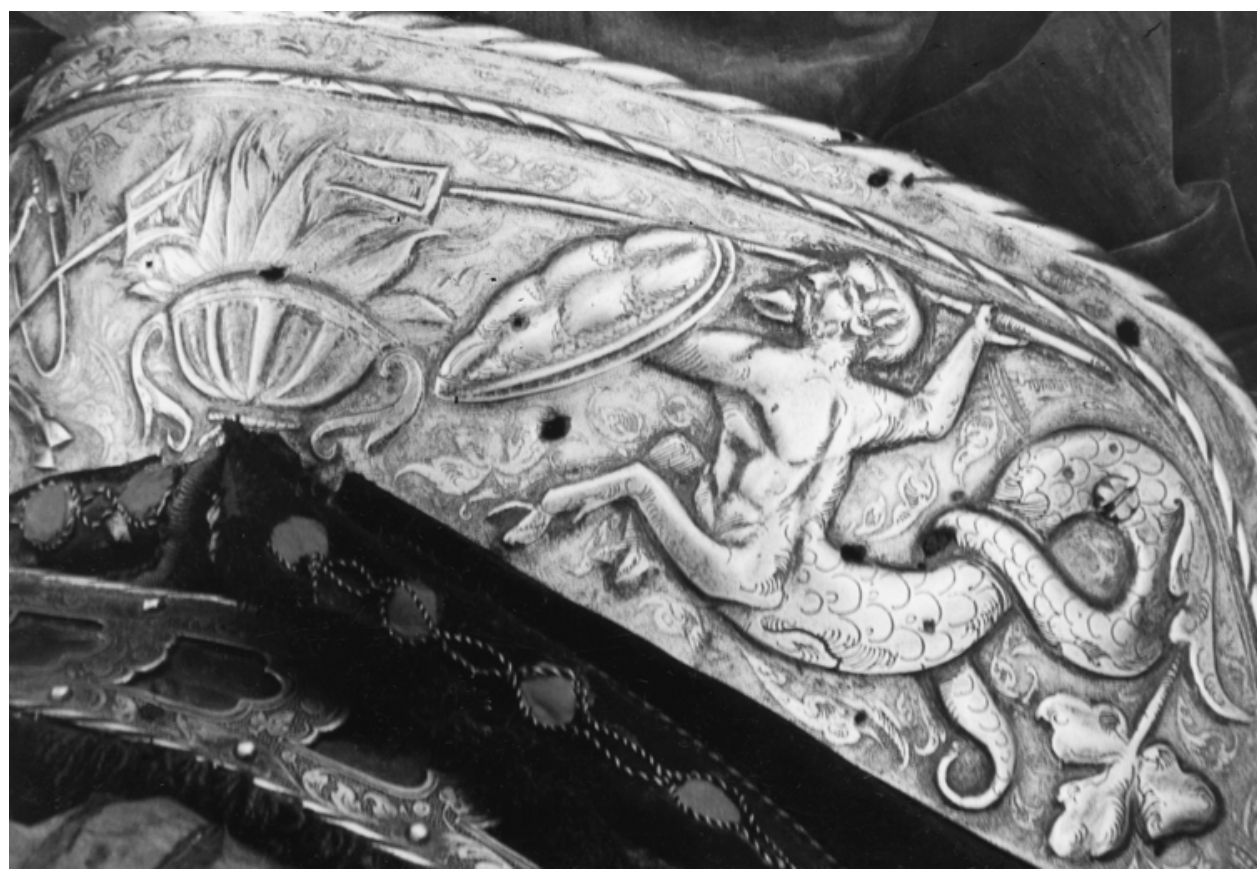

Fig. 10. Silla de montar. Detalle del arzón trasero. Real Armería, cat. A-149. 
flanqueada por las figuras de dos centauros marinos armados (uno con escudo puntiagudo y el otro con un tridente), vistos de perfil y en marcado contraste, por su actitud de dinamismo, con la figura de la sirena. La simbología de las sirenas, unida al pecado carnal, la voluptuosidad y los peligros que acechan al hombre en el mar, no parece ser apropiada en el marco decorativo que ocupa por lo que sugerimos que su presencia no encierre, en esta ocasión, un significado iconológico profundo y que, simplemente, haya servido para aludir al mar y a la soberanía marítima de Carlos V.

El arzón delantero está decorado con una pareja de habitantes marinos fabulosos afrontados entre sí: un ser masculino alado de extremidad anguípeda y una figura femenina de extremidad pisciforme, también alada, de larga y rizada cabellera, cuya iconografía presenta similitudes con las representaciones del monstruo marino femenino denominado «la Serra», conocido a través de los comentarios de los bestiarios medievales y representado en la iluminación de los manuscritos de aquel tiempo ${ }^{64}$. El conjunto se completa con la presencia de otros dos anquípedos alados que decoran la perilla.

Ictiocentauros análogos a los mencionados en la silla A.150, en clara actitud de combate, ocupan el campo decorativo de otro arzón trasero (A.149) realizado por el mismo armero en idéntico lapso de tiempo (fig. 10). Se disponen, en esta ocasión, afrontados en torno a un jarrón central repleto de plantas, y portan sendos tridentes y escudos similares a caparazones de tortugas, de acuerdo con esquemas y actitudes de simetría inversa; su ademán es igualmente dinámica y la extremidad pisciforme que poseen presenta dos remates, uno tripétalo y otro que se enrolla sobre sí mismo. La presencia de estas figuras, muy parecidas entre sí y reiteradas en numerosas composiciones, hace pensar en la utilización de los libros de patrones a los que ya nos hemos referido, de los que se tomarían, en cada caso, algunos motivos, de acuerdo con diferentes combinaciones, para elaborar, a la postre, diseños únicos.

Las sirenas en actitud heráldica, enfrentadas entre sí, de acuerdo con los modelos ofrecidos por los manuscritos iluminados del siglo XIV, pueden verse en la decoración del peto fuerte ya citado (M-10) de Carlos V, ocupando el espacio central de la cintura. Sostienen cuernos musicales en sus manos, y sus imágenes se unen en el remate de sus extremidades pisciformes. La simetría del conjunto se enriquece con hojas acuáticas cuya disposición sirve para llenar los vacíos del espacio decorativo.

Finalmente merece mención la barda A.65 (fig. 11), cuya banda perimetral, decorada al aguafuerte, contiene representaciones de batallas de dioses marinos, tal y como habían puesto de moda las estampas de Mantegna y Durero ya citadas. Las figuras presentan gran variedad, algunas son anguípedos, otros personajes casi humanos que cabalgan a lomos de hipocampos, pero todos ellos van convenientemente armados y se aprestan, con dinamismo y no poca expresividad, a la contienda.

\section{LAS ARMADURAS DURANTE EL REINADO DE FELIPE II}

Desde 1550, puede apreciarse un cierto cambio en los repertorios decorativos de las armas reales, probablemente por las preferencias personales de Felipe II. Roleos, cintas, lacerías, flores, cruces de Borgoña, aspas, eslabones y el collar del Toison y, en definitiva, toda suerte de motivos, muchos de ellos con connotaciones dinásticas, constituyen la temática elegida, en la mayoría de los casos, por el monarca. El rey heredó el gusto de su progenitor por las guarniciones elegantes, y encargó, como es bien sabido, algunas de sus armaduras al

64 La Serra, según los bestiarios medievales, es un monstruo provisto de alas y una cresta en forma de sierra con la que corta a los barcos. Todos los textos se refieren a su extraordinaria velocidad. Cfr. Bestiario medieval (edición a cargo de Ignacio MALAXECHEVERRíA), Madrid, 1986, pp. 68-72. 


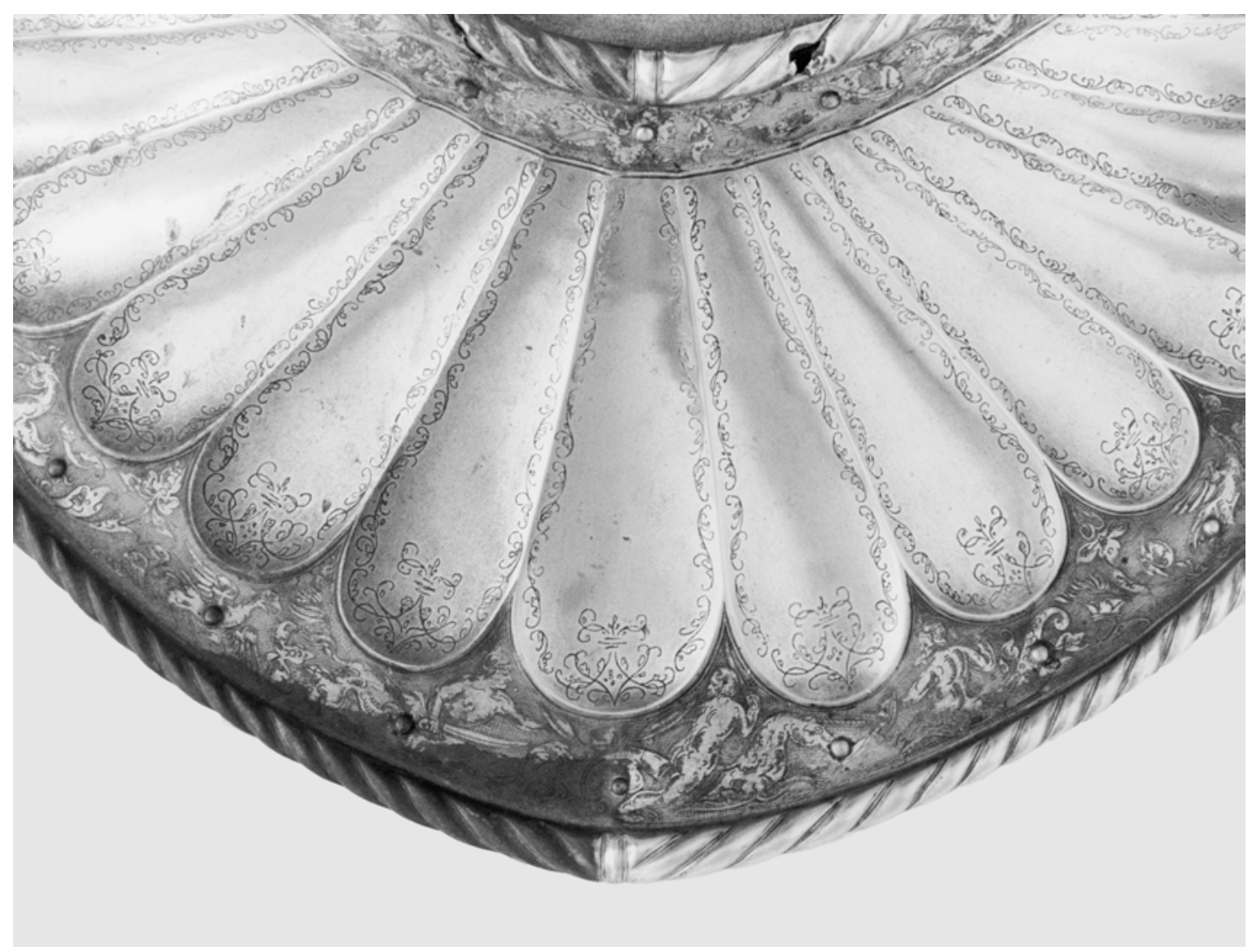

Fig. 11. Barda de caballo. Detalle frontal de la pechera. Real Armería, cat. A-65.

armero preferido de su padre, Desiderius Helmschmid, aunque pronto se decantó por los trabajos del armero Wolfgang Grosschedel de Landshut, hecho que determinó la decadencia de Augsburgo como centro productor y el cierre de gran número de sus talleres.

Grosso modo, podemos señalar que la decoración de asunto marino presenta escenas mitológicas cuyo contenido simbólico ha cedido en parte, quedando convertida en muchos casos, en un repertorio puramente ornamental, muy elaborado y de fina factura, que reproduce modelos ya conocidos en el reinado anterior, ahora tratados con una alta dosis de artificio, dentro del manierismo estilístico imperante en el arte europeo de su tiempo. El motivo del delfín, tan característico de las armaduras de Carlos V sólo puede vislumbrarse ocasionalmente en las obras de este período, como sucede, por ejemplo en la llamada armadura de lacerías (A.189-A.216), obra de Desiderius Helmschmid y del grabador Ulrich Holzmann, fechada en 1544-1546.

Los motivos marinos más utilizados en la decoración de este período están en relación con escenas del antiguo thíasos marino, tomados de arquetipos del arte romano imperial y que poseen carácter ornamental y propagandístico. Son, ante todo, bellos motivos en los que los artistas hacían revivir el espíritu de la Antigüedad, recuperado en toda su plenitud, desde finales del siglo XV, en la dimensión estilística y formal de sus modelos. La iconografía de estos asuntos marinos aplicada a las armaduras de lujo de la primera mitad del siglo XVI encuentra sus más bellos prototipos en las realizaciones del taller milanés de Filippo Negroli, cuya influencia se dejó sentir notablemente en Europa en la segunda mitad del siglo. Son muchas las armas de parada fabricadas en el citado taller milanés que presentan decoración 
marina, con sirenas, tritones, ictiocentauros, o escenas de thíasoi como protagonistas ${ }^{65}$; tan bellos modelos de inspiración serían recreados en los más importantes centros de fabricación de armas europeos.

Entre las armaduras hechas para el rey Felipe II destaca la realizada por Antón Peffenhauser (1525-1603), de Augsburgo (A.290) (figs.12 y 13), que se ha fechado por razones estilísticas en torno a $1560^{66}$. Presenta exhuberante decoración repujada, hecho poco habitual en los talleres alemanes, a través de la cual se ha pretendido expresar una alegoría del poder real. De tales motivos destacamos, en esta ocasión, los relacionados con la mitología clásica entre los que no podían faltar los marinos. La borgoñota presenta, a ambos lados de su cresta, una figuración relacionada con escenas del thíasos marino de la Antigüedad, inspiradas en los relieves que ornaron en su día los frentes de los sarcófagos antiguos y otras artes decorativas.

Neptuno, cabalgando sobre una pareja de hipocampos e identificado por su tridente, ocupa una posición central a ambos lados de la cresta. En uno de los lados de la misma, el dios va precedido por un fuerte tritón que hace sonar su caracola y otros seres marinos fabulosos (delfín y ciervo marino de gran cornamenta); le sigue un sátiro de extremidades caprinas (que sostiene en sus manos un cuerno de la abundancia), y una figura femenina montada en un carro tirado por aves, tal vez representación de Afrodita (en su acepción de divinidad marina) tras la que aparece un grifo marino que cierra el conjunto. En el lado opuesto, el cortejo mítico está encabezado por varios peces y un terrible monstruo marino con semblante de cánido (como el Kétos de la Antigüedad), tras el que se han representado dos parejas: Neptuno y Anfítrite - que ocupan el centro del marco compositivo- y Tetis y Océano, divinidades primordiales pertenecientes a la primera generación de los Olímpicos. Anfítrite va montada sobre un enorme delfín de fauces amenzadoras y Neptuno se identifica, en esta ocasión, por la potencia muscular que exhibe, su posición central, y por la cabalgadura sobre la que avanza (idéntica a la del lado opuesto). Tetis se recuesta sobre un delfín monstruoso, similar al ya citado, mientras deja ondear al viento su manto flotante, y Océano (la figura que cierra el conjunto por este lado) aparece en actitud de hacer surgir su poderoso caudal (similar alegóricamente a una sierpe marina) entre sus piernas. Tetis y Océano poseen pinzas de crustáceo que ornan sus venerables sienes, de acuerdo con los modelos iconográficos habituales de los mosaicos tardorromanos.

El estilo de la pieza es profuso, abigarrado, resultando la superficie totalmente ocupada por motivos decorativos, con un marcado sentido del horror vacui. Parece como si a través de estas obras hubiera comenzado a disolverse el clasicismo y la ordenación de las figuras para dar paso a una manera caracterizada por el dinamismo, y, en cierto sentido, barroquizante. Las figuras tienen proporciones muy alargadas, manieristas, y sus cuerpos responden, por lo exagerado de su musculatura, al estilo romano de herencia miguelangelesca.

El sentido de protección que los seres marinos procuran al propietario de la armadura se ratifica de un modo especial en esta singular producción, por la abundancia de seres de la mitología marina que sirven para decorarla. A ambos lados de la nuca de la borgoñota que analizamos podemos ver a dos figuras recostadas sobre enormes delfines; una de ellas, masculina, ostenta tridente y cántaro manante, atributo éste último que la identifica como divinidad primordial de carácter fecundo, y que podría identificarse con Océano o Nereo, el anciano del Mediterráneo sometido más tarde al Poseidón aqueo. La otra figura, femenina, también está identificada como divinidad marina por un tridente, y por cabalgar recostada a lomos de un delfín, como ya hemos apuntado, aunque sobre sus sienes el artista ha colocado una diadema con el creciente lunar característico de Ártemis-Diana. Es preciso señalar, en

65 Cfr. PyhrR, S.W./Godoy, J.A., op. cit., nn. 33, 35,36,39,41,43,44 y 46.

66 Cfr. Welt im Umbruch. Augsburg zwischen. Renaissance und Barock, Band II, Augsburgo, 1980, pp. 513-14; Felipe II. Un monarca y su época. Un príncipe del Renacimiento, Museo del Prado, 1998, n.73. 

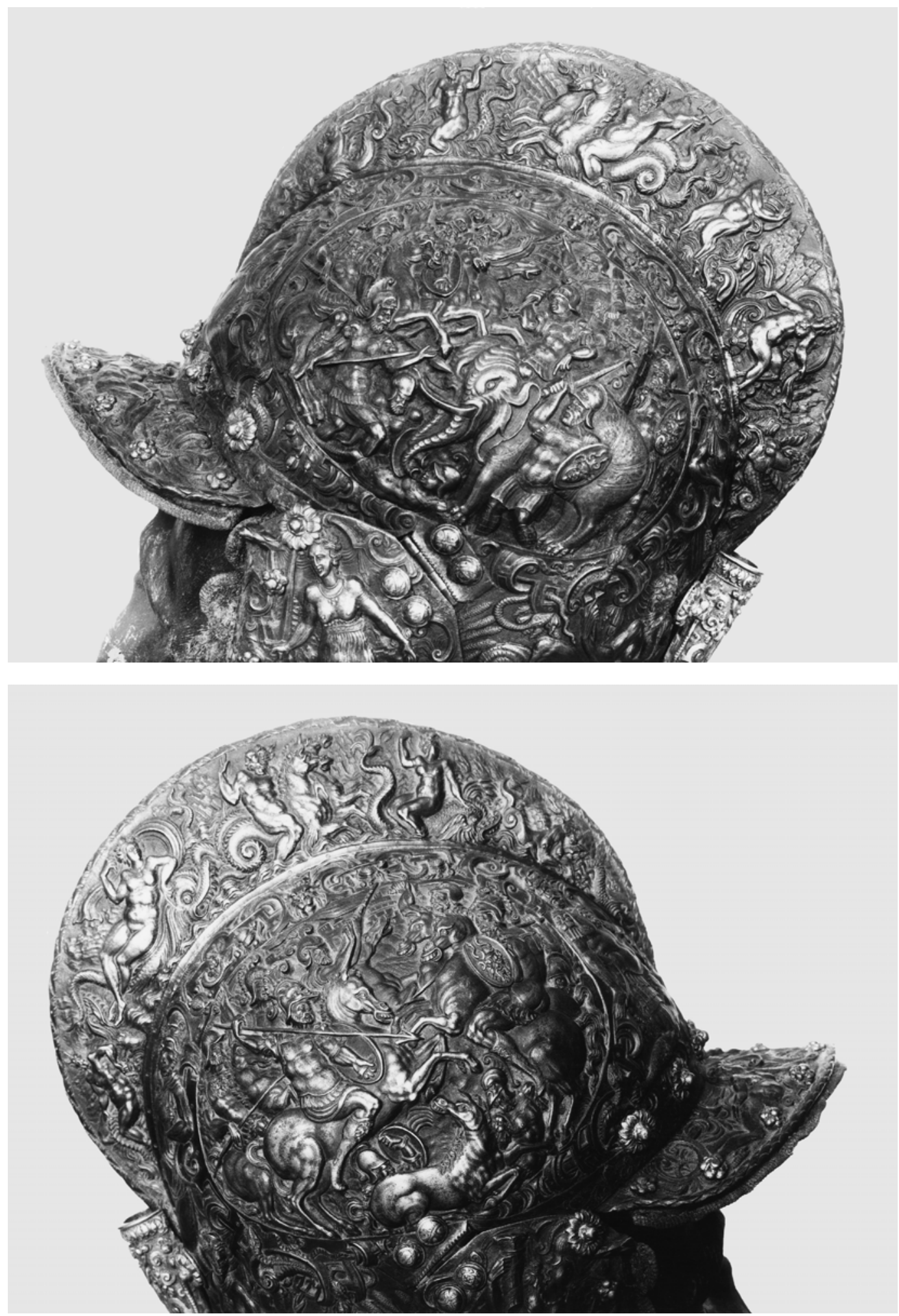

Fig. 12-13. Borgoñota. Detalles de la calva. Real Armería, cat. A-290. 
este punto, que las recreaciones modernas de los temas iconográficos antiguos sufrieron, en muchos casos, un proceso de contaminatio, de tal suerte que las figuras presentan cierto eclecticismo que puede llegar a dificultar su correcta designación. En el caso que nos ocupa, no cabe duda de que se trate de una divinidad marina, Doris o Tetis, aunque por su cabeza pudiera relacionarse con Ártemis.

Sobre el cuello de la misma borgoñota han sido figurados, asimismo, un tritón y un tritonisa cuyas extremidades pisciformes, casi mutadas en foliaciones vegetales, son similares a las habituales en los motivos de decoración «al grutesco». La visera ofrece las imágenes de dos personajes recostados, en actitud natatoria (actitud idéntica a la que ofrecían las personificaciones de las nereidas en el arte romano); creemos que pueda tratarse de una pareja de dioses marinos pertenecientes a la primera generación divina, Doris y Nereo, o bien Océano y Tetis, inclinándonos por ésta última hipótesis, dado que el único atributo iconográfico que las identifica es una sierpe marina.

Además, en el antebrazal izquierdo, puede verse una sirena de extremidad pisciforme bífida y entrelazada, prototipo que hunde sus raíces en la miniatura altomedieval y que tuvo gran difusión en el siglo XVI, quizás por las variadas posibilidades compositivas que ofrecía a los artistas. El mismo lugar, en el brazo derecho, lo ocupa la representación de un sátiro, lo que subraya, una vez más, la relación entre los seres míticos del mar y los integrantes del cortejo dionisíaco.

Felipe II, acaso menos aficionado al deporte que su padre, cesó de encargar armas de justa hacia 1554, y sin embargo, poseemos varios juegos de parada ${ }^{67}$ contemporáneos a su reinado, que son elocuentes testimonios de los gustos difundidos entonces entre príncipes y nobles, así como de la complejidad creciente de su decoración. La colección de la Real Armería de Madrid posee varios de estos conjuntos de fabricación italiana, fechables hacia 1560, en los que los temas decorativos más recurrentes proceden de la mitología clásica, y en los que también está presente la mitología del mar. A este grupo pertenece, por ejemplo, la borgoñota D.3 (fig. 14), en cuya cresta podemos contemplar un combate entre ictiocentauros armados (con arco y maza respectivamente); el conjunto se completa con la figura de una nereida sentada lomos de uno de ellos y, en los extremos, con dos figuras de sátiros de patas caprinas. El otro lado de la pieza presenta otro combate, protagonizado por centauros y seres humanos, posible alusión a la Centauromaquia.

En el juego de parada D.5 y D.6, la iconografía de asunto marino decora tanto la rodela como la borgoñota (fig. 16). La rodela (D.5) ostenta en su centro un mascarón de gesto expresionista, cuya boca hace pensar en la imagen más arcaica de la terrorífica Medusa; este emblema central está flanqueado por diversas escenas de lucha y una banda perimetral espléndida en la que, además de cuatro medallones con bustos antiguos, se ha representado un thíasos marino a la antigua en el que podemos contemplar idilios entre centauros marinos y sus paredras, ictiocentauros que luchan con tritones o con otros seres de su misma especie, mientras otros intentan domar a rápidas cabras marinas, dragones y leones marinos, tritones moribundos, tritonisas de extremidad pisciforme bífida, nereidas que cabalgan sobre ictiocentauros o dos seres humanos que vuelcan cántaros manantes ${ }^{68}$. Sólo los más espectaculares conjuntos del arte musivario romano de época imperial igualan la fantasía iconográfica dada en esta obra, finísimo trabajo en todos los sentidos. La borgoñota (D.6) que hace juego con ella exhibe seres anguípedos de compleja filiación sobre la visera y la cresta, seguramente figuras con sentido apotropaico.

67 El armero milanés Filippo Negroli pasa por ser el creador de los llamados juegos de parada, integrados por una borgoñota y una rodela, según el modelo básico de la Antigüedad. Dichos conjuntos se popularizaron desde 1533 con los trabajos que este artífice realizó para Carlos V, y siguieron siendo objetos exquisitos, durante el reinado siguiente.

68 Para estas últimas figuras no existen prototipos similares en el arte clásico, ya que habitualmente corresponde a Océano o a las figuras de los ríos (sus hijos) la misión de hacer brotar caudales, siendo su iconografía la de seres de edad avanzada y recostados, no hombres jóvenes y sedentes como los que pueden verse en la obra analizada. 


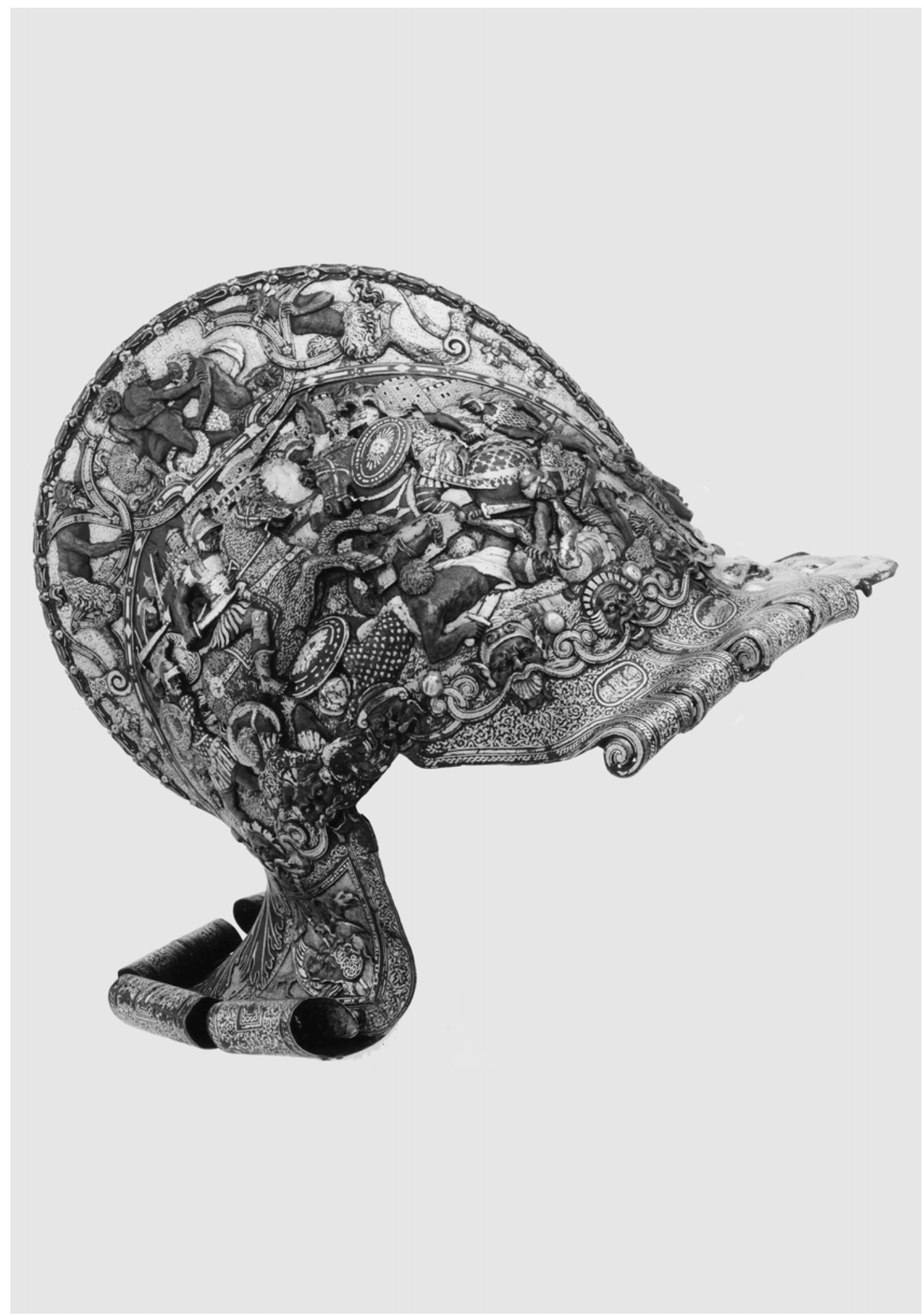

Fig. 14. Borgoñota. Real Armería, cat. D-3. 


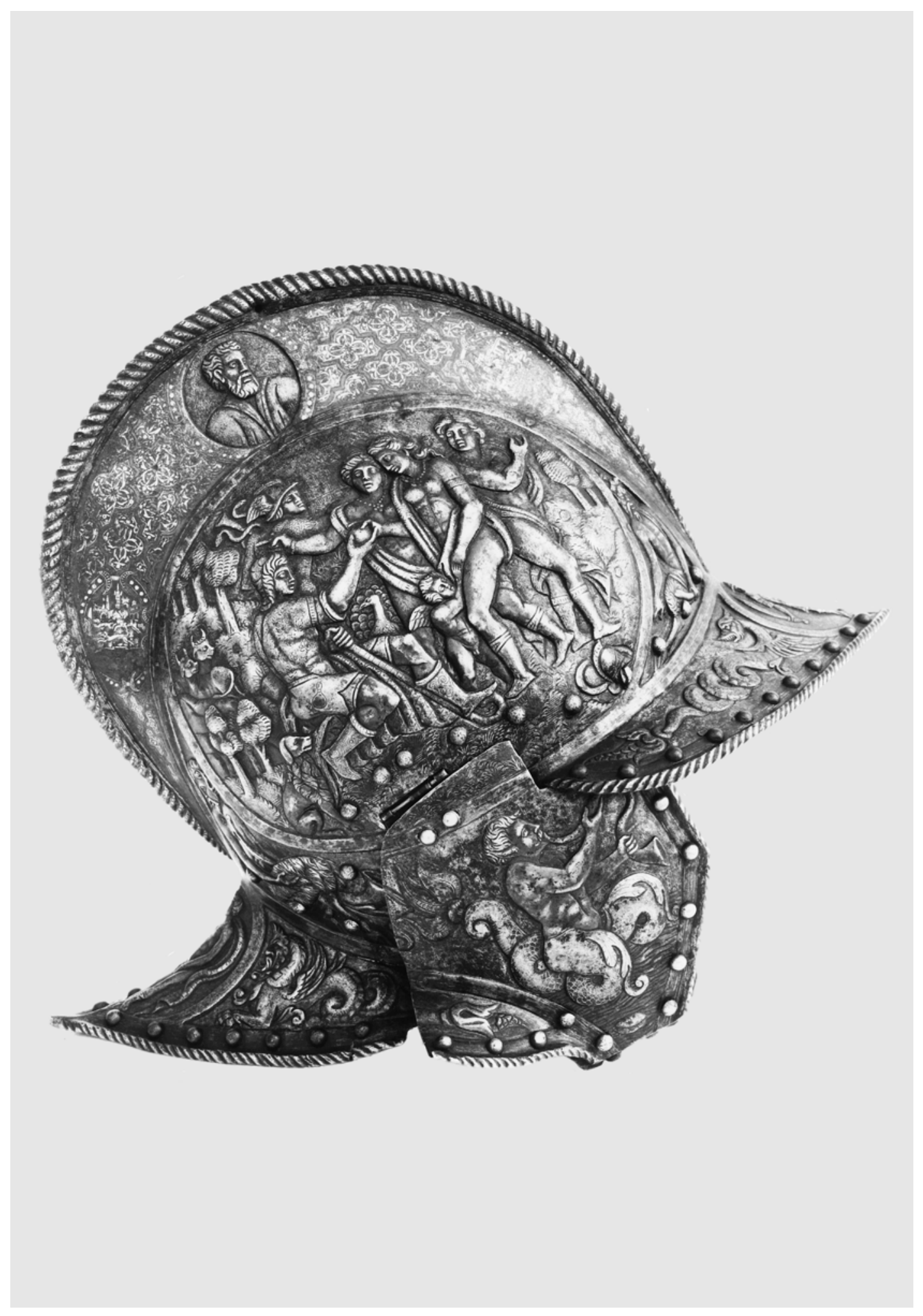

Fig. 15. Borgoñota. Real Armería, cat. D-7. 


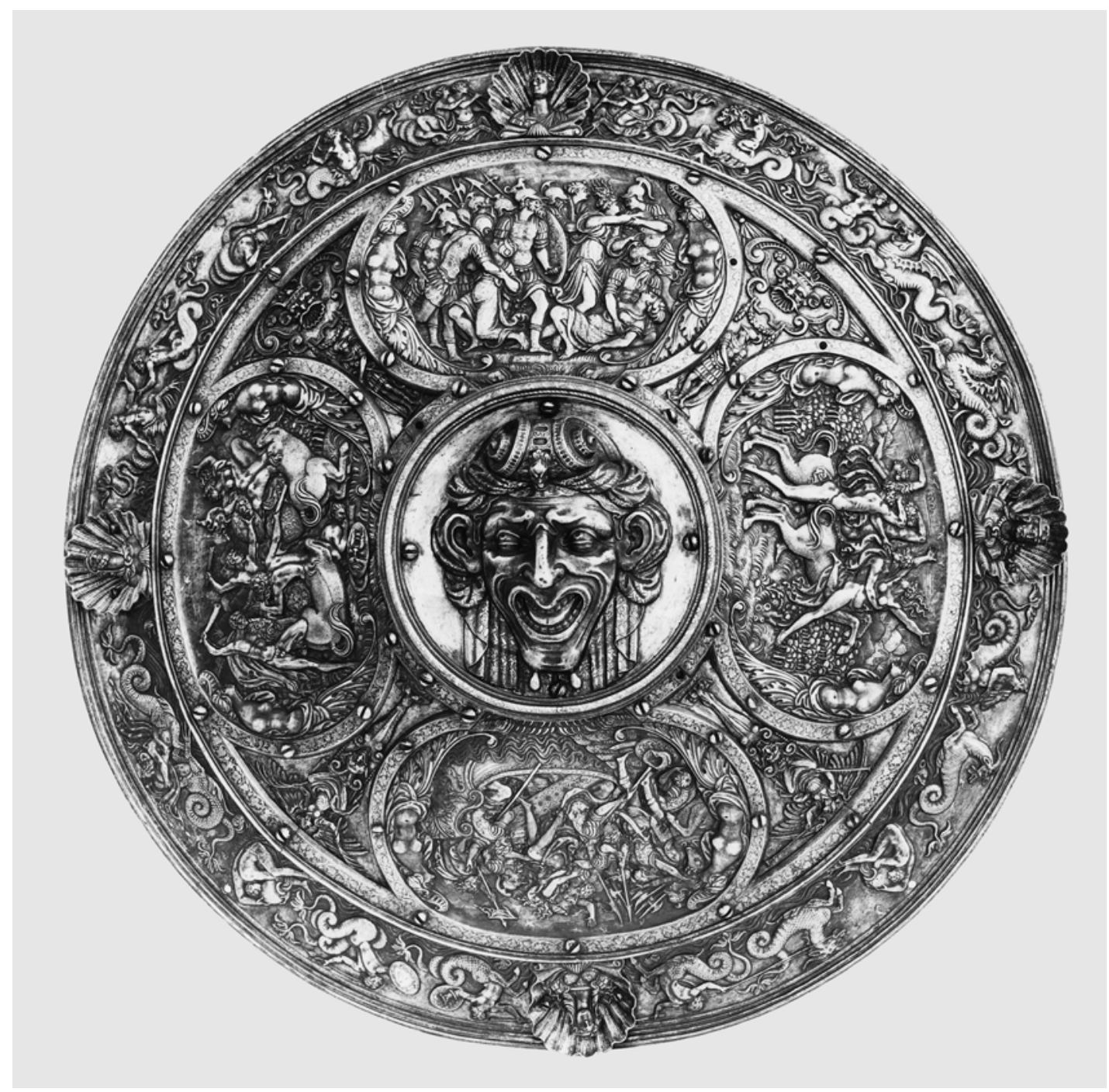

Fig. 16. Rodela. Real Armería, cat. D-6. 


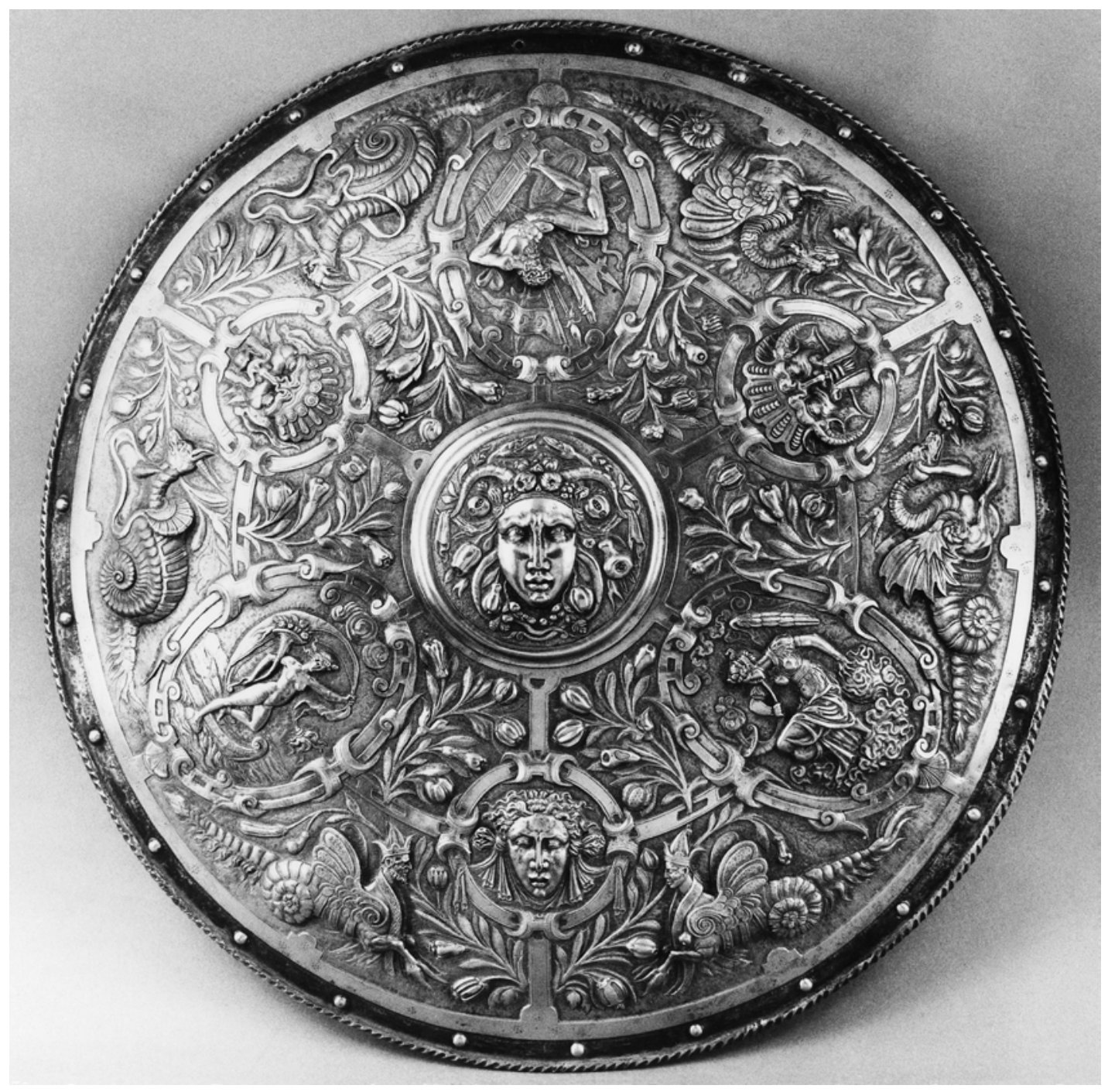

Fig. 17. Rodela. Real Armería, cat. D-72. 
La borgoñota D.7 (fig. 15) presenta motivos iconográficos marinos ubicados en diferentes lugares. Sendos tritones de extremidad pisciforme bífida decoran las carrilleras ${ }^{69}$ : uno de ellos hace sonar una caracola marina, mientras que la otra figura (provista de unas prominentes mamas colgantes, según prototipos iconográficos dados por la iconografía de las sirenas medievales), sostiene dos peces en su mano. Dos hipocampos alados (con típica «ala pérsica») cubren el espacio decorativo sobre la nuca y un monstruo marino de cola muy enrollada (similar también a los conocidos en los manuscritos medievales) ha sido representado sobre la visera. La rodela del mismo juego de parada (D.8), tiene como motivo principal en su decoración el rapto de Helena, episodio legendario que dio origen a la guerra de Troya. Desde el agua emerge un habitante de las profundidades, un gran delfín, cuya presencia obedece a la mera ambientación de la escena.

La citada línea iconográfica de seres marinos en actitud de combate se puede apreciar en la rodela D.70. De las ondulaciones marinas surgen cabezas de monstuosos animales y varias parejas de ictiocentauros que luchan ${ }^{70}$, afrontados entre sí, mientras que otros congéneres acuáticos avanzan, en solitario, a través de su elemento.

La rodela D.72 (fig. 17) resulta también muy interesante a nuestros ojos, por la rareza de su iconografía. Una mascara, provista de cuernos, ocupa el umbo central de la pieza, mientras que otros tres mascarones -inscritos en círculos- alternando con las alegorías de la Guerra, la Fortuna y la Abundancia - dentro de marcos ovalados- se disponen sobre su superficie, ornada también con decoraciones vegetales y seis seres marinos fabulosos. Estos últimos, todos ellos alados y de cuerpo rematado en una poco usual extremidad marina, análoga a la de las langostas y otros crustáceos, son excepcionales desde el punto de vista iconográfico; cuatro de ellos poseen cabezas de imaginarios y terroríficos animales, mientras que los dos inferiores tienen cabeza humana, tocada por una corona, y extremidades delanteras semejantes a las que son habituales para los centauros marinos.

La barda A.243 del príncipe D. Carlos, forjada por Kunz Lochner de Nuremberg, está decorada, entre otros motivos, con las figuras de cuatro delfines: dos de ellos, los situados en la parte delantera poseen formas que responden a un naturalismo algo esquematizado, mientras que la pareja ubicada en la zona posterior responde a modelos muy hibridados, y sus extremidades se confunden con lo vegetal, formando un entramado caprichoso y fantástico muy acorde con los postulados decorativos tomados de los repertorios gráficos antedichos, siempre elegantes en su concepción.

Una espléndida silla italiana de mediados del siglo XVI (F.51) (fig. 18) presenta en el arzón delantero a Neptuno conducido a través de las ondas en un carro tirado por cuatro caballos marinos y flanqueado por dos tritones de extremidad bífida que hacen sonar sus instrumentos. El dios, del que sólo es visible el torso y la cabeza, empuña su tridente con la diestra, mientras que calma la furia del oleaje con la otra mano ${ }^{71}$. Su rostro es enérgico y su musculatura poderosa; el cabello y la clámide flotan henchidos por la brisa marina. Los corceles que arrastran su embarcación son dinámicos y expresivos, y sus cuerpos, plagados de un tejido escamoso muy detallado, se confunden con las ondulaciones del mar en el que

69 Es muy habitual que las carrilleras de las borgoñotas ofrezcan un espacio decorativo en el que disponer figuras de seres marinos. Ya en la Antigüedad, algunos yelmos muestran motivos marinos en dichas piezas. En el Renacimiento la costumbre se generalizó, como demuestran, por ejemplo, algunas piezas sobresalientes de la colección de la Armería de Viena (A.936, A.802). Cfr. Katalog der Leibrüstkammer. II Teil. Der zei traum von 1530-1560, Kunsthistorisches Museum, Viena, 1990.

70 Son muy numerosas las piezas que presentan decoración basada en el combate de ictiocentauros o de éstos con tritones. Por citar algunos ejemplos que puedan servir de paralelos iconográficos a las piezas que venimos estudiando, véase Musée d'Artilleria, Ministère de la guerre, Berthand, 1895, I, 79; III, 116 y 123.

71 Esta actitud de Neptuno calmando la furia de las olas está en relación con el pasaje de la Eneida I, 135: Quos Ego..., que popularizó Marcantonio Raimondi en una estampa, basándose en un dibujo de Rafael, Cfr. DELABORDE, op. cit., pp. 147-148. 
habitan. A ambos lados del dios hay dos tritones, algunos peces, una máscara barbuda que representa al Océano y dos amorcillos, figuras que integran el séquito triunfal de Neptuno.

En el arzón trasero de la misma pieza un terrible monstruo marino ocupa el espacio central y dos dinámicos tritones de colas bífidas que empuñan un tridente y una cimitarra respectivamente, intentan contener la furia del abismo marino; a ambos lados, un tritón juvenil que hace sonar su cuerno y un erote que revolotea en el lado opuesto, completan el soberbio conjunto.

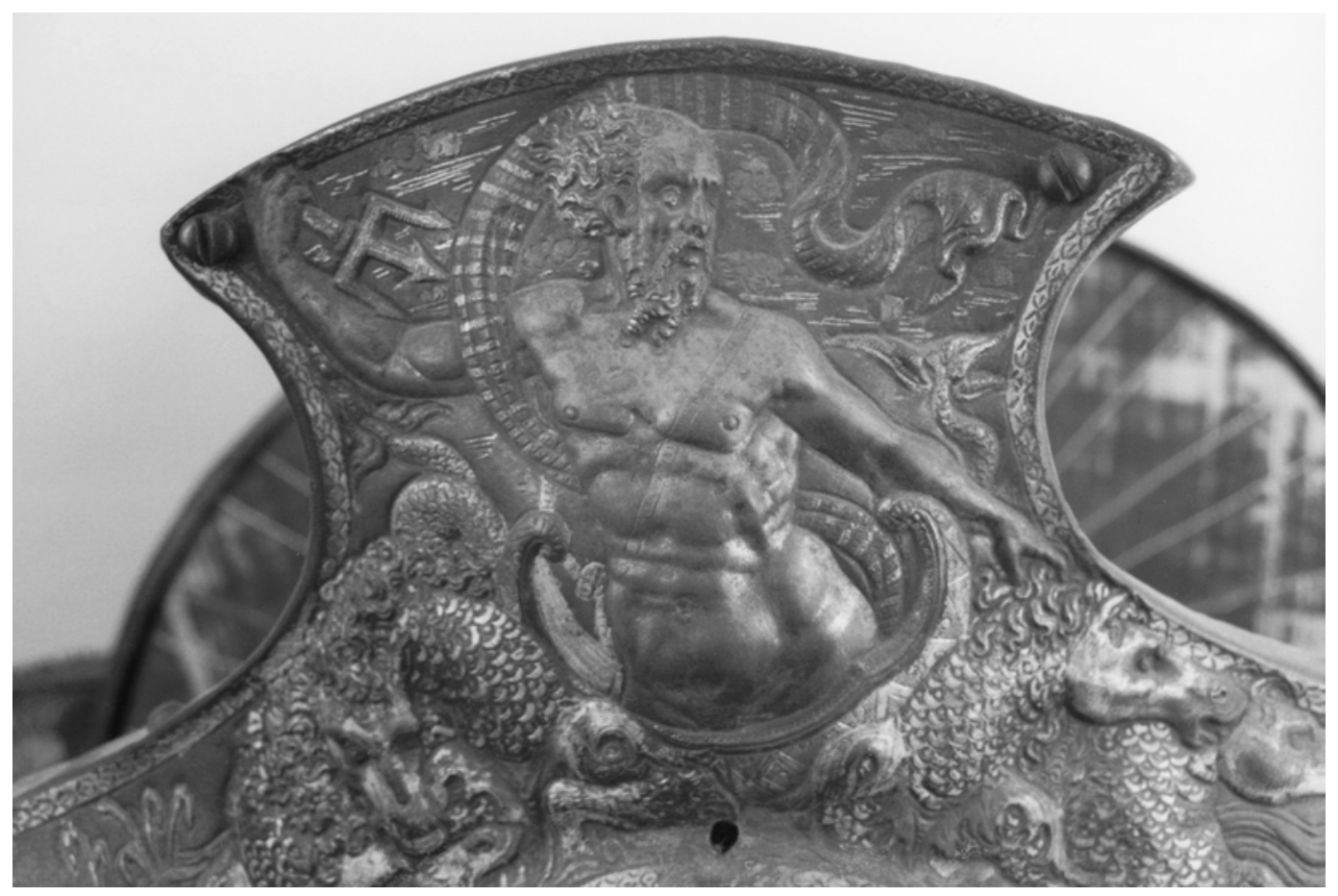

Fig. 18. Silla de montar. Detalle del arzón delantero. Real Armería, cat. F-51.

Por su parte, la silla A.359 presenta un arzón trasero decorado con delfines, mientras que en el arzón delantero el espacio decorativo está ocupado por sirenas aladas de extremidades pisciformes entrelazadas, de acuerdo con los modelos medievales ya señalados, que se asemejan a las piernas humanas.

Para finalizar este acercamiento a las armaduras de la época que tratamos, merecen citarse las realizadas para Felipe III niño. La armadura B.4 presenta anguípedos alados de cola bífida (según arquetipos del arte etrusco) en los hombros, y en el espaldar sendas parejas de delfines cruzados con las cabezas hacia abajo, en direcciones opuestas; las escarcelas tienen imágenes de tritones cuyas colas se entremezclan con motivos de decoración «al grutesco». En la celada B.1, el dorso de la calva presenta, a ambos lados del eje central, sendas parejas de tritones separados por un mascarón, y la vista, una cabeza-mascarón monstruoso que recuerda a Océano. En la pieza B-7 pueden contemplarse figuras de delfines grabados en el borde del espaldar, mientras que en el cuello del espaldar de la B.6 los motivos decorativos son elegantes anguípedos alados, metamorfoseados con elementos vegetales, y dispuestos con simetría.

La rodela italiana B.3, realizada en acero repujado a finales del siglo XVI, también para Felipe III niño, muestra un medallón central en el que Neptuno aparece, junto a sus hermanos Júpiter y Marte, combatiendo a las flotas moriscas; los dioses, desde el Olimpo, asisten a los 


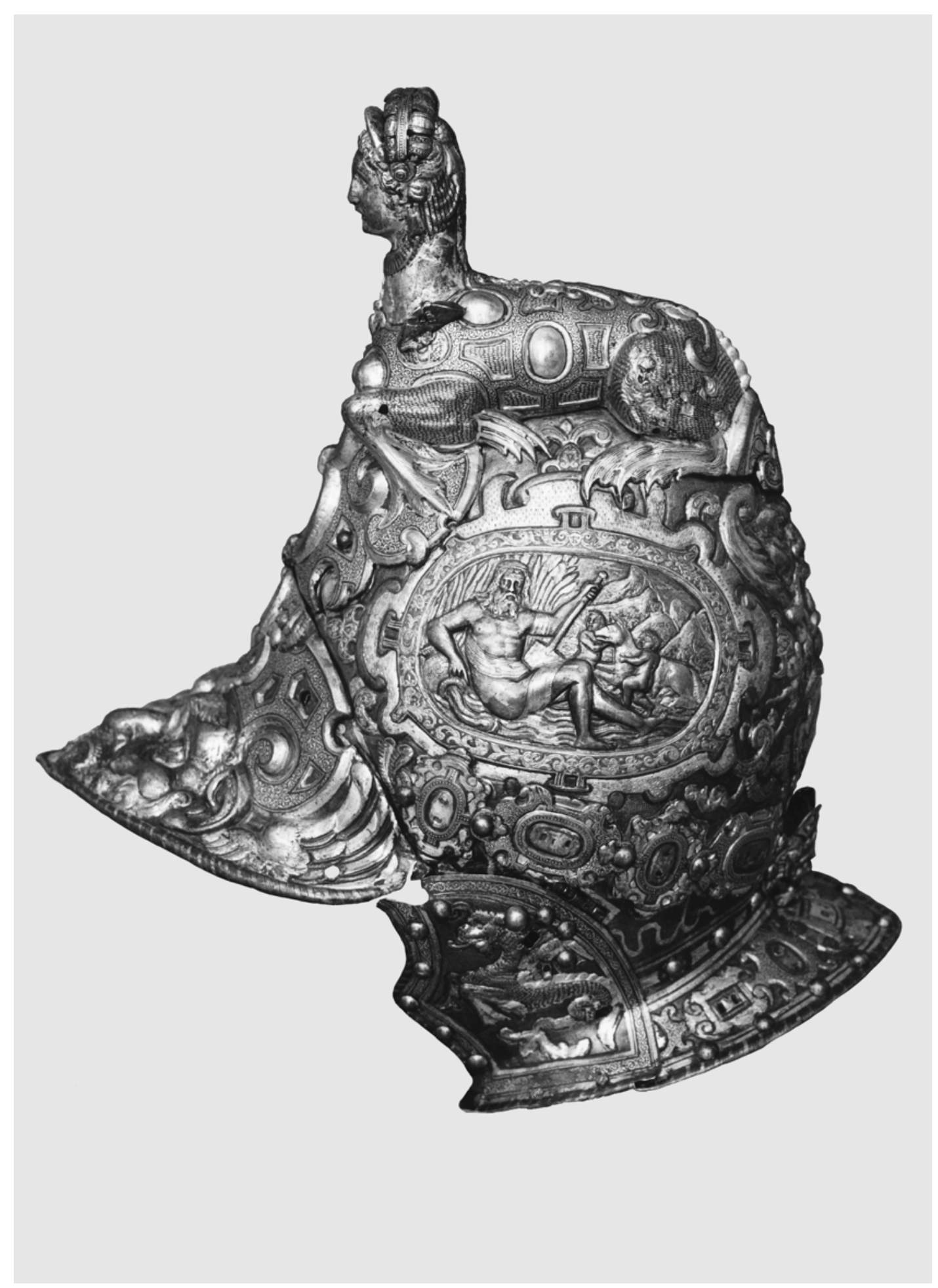

Fig. 19. Borgoñota. Real Armería, cat. A-292. 
reyes españoles en la batalla. Alrededor de la escena central se disponen cuatro cartelas con escenas militares y alegóricas, entre las que se puede advertir la presencia de cuatro réplicas de la Ártemis «polimasta» de Éfeso, alzadas sobre estípites ${ }^{72}$ y flanqueadas, dos a dos, por águilas y caballos marinos alados. El capacete B.5 presenta una cabeza-mascarón similar a las representaciones de Océano.

La barda regalada por Carlo Manuel I de Saboya a Felipe III, procedente de la colección Rothchild muestra, en el lateral izquierdo, la imagen de un tritón con remate de cola tripétala que lleva una caracola en su mano, aunque no hace ademán de tocarla; los antecedentes iconográficos para esta figura hay que rastrearlos en los mosaicos romanos de los siglos I y II d. C. En la misma pieza se puede contemplar una pareja de humanos montados sobre animales marinos. El lateral derecho contiene la imagen de un tritón similar al anterior que sopla su caracola marina, y una pareja de humanos que, cabalgando a lomos de hipocampos, portan tridentes en sus manos.

Perteneciente a la misma armadura, la borgoñota milanesa A.292 (fig. 19), datada hacia 1585 , es sugestiva muestra iconográfica, porque todos y cada uno de los elementos que la decoran sirven para subrayar el carácter defensivo de la pieza: la esfinge que la corona, las dos personificaciones del Océano (o río) enmarcadas en óvalos laterales, y los monstruos anguípedos alados de difícil designación que, en esta ocasión, ocupan las carrilleras.

La Rodela de Eugui (Navarra) (D.73) fue realizada en España por armeros milaneses para Felipe III $^{73}$. Posee un friso exterior decorado con grifos marinos cabalgados por erotes y dos unicornios marinos en la parte superior, también montados por seres humanos. Flanqueando la escena central (Juicio de Paris) hay cuatro personajes a lomos de delfines, y otros anguípedos fantásticos sirven para rellenar el espacio decorativo.

\section{CONCLUSIONES}

La iconografía y la forma de las piezas que hemos estudiado en las líneas precedentes nos permite vislumbrar que ambos aspectos, el iconográfico y el formal, fueron concebidos de acuerdo con un proceso de pausada reflexión, para responder a la demanda de una época en la que símbolos y formas se imbricaron en una alianza indisoluble. Dicha alianza contribuyó, en cierta medida, a forjar una imagen política que fuera la más adecuada para el príncipe, reforzando el carácter protector de la propia armadura.

Todos y cada uno de los aspectos que configuran las armaduras en los reinados de Carlos $\mathrm{V}$ y Felipe II estuvieron interrelacionados de una forma tan perfecta, que no se pueden desligar entre sí el diseño, la decoración y la técnica de realización. La suma de todos los elementos de la armadura determina un resultado artístico de extraordinaria calidad que pone ante nuestros ojos obras originales, caprichosas y hasta extravagantes en algunos casos, como exponentes de una época caracterizada por el refinamiento y el amor por el lujo. No cabe, por tanto, en ningún caso, relegar el papel de la iconografía en el estudio de estas obras, cuyo interés consideramos esencial para el conocimiento profundo de las mismas.

72 La presencia de la Ártemis efesina fue un motivo iconográfico repetido con cierta frecuencia en las armaduras de la época que nos ocupa, tomado probablemente de los libros de patrones. Como ejemplo baste citar el magnífico escudo de Alejandro Farnesio, de 1570, en Viena. Cfr. BoEHEIM, W., Kunsthistorische Sammlungen des Allerhöchsten Kaiserhauses, II, XV.

73 La armería italiana de Eugui (Navarra) comenzó a funcionar en 1595 con un equipo especializado de armeros que, expatriados en 1595, se establecieron en tierras navarras por deseo de Felipe II. Su historia concluyó en 1630, cuando se abrió una nueva fábrica en Tolosa. En Eugui se fabricaron algunas de las armaduras de los hijos de Felipe III, seguramente basadas en modelos decorativos y croquis que los milaneses trajeron consigo de Italia. Cfr. GodoY, J.A., «Armeros milaneses en Navarra: la producción de Eugui», Gladius, Tomo XIX (1999), pp. 231-260. 
Ya hemos señalado que la iconografía de los seres de la mitología clásica del mar obedece, fundamentalmente, a razones simbólicas y decorativas. Hemos podido comprobar que, en el plano simbólico, es muy dilatada la tradición iconológica que relaciona a las criaturas marinas con la garantía de inmortalidad y con la soberanía marítima. De todas ellas, la imagen del delfín constituye un motivo iconográfico de gran interés, por la complejidad y riqueza de su simbología. Durante el reinado de Carlos $\mathrm{V}$, merece señalarse la frecuencia de los delfines como motivos decorativos en las piezas que sirven para cubrir la cabeza, acaso para simbolizar la inteligencia del guerrero o justador. Fue asimismo frecuente que las cabezas de delfines estuvieran situadas en los guardamaslos, ubicación que entendemos no sólo como símbolo apotropaico sino también, quizás, como aval que pudiera proporcionar, simbólicamente, velocidad al caballo.

En el plano decorativo merece resaltarse que las extremidades pisciformes de los seres marinos son formas que se adaptan fácilmente a cualquier marco, sin menoscabo alguno de su belleza. La naturalidad con la que éstas pueden someterse a diversas exigencias compositivas es un factor, que sin duda, debió de contemplarse a la hora de elegir estos asuntos iconográficos. Son seres cuyas colas pueden enroscarse, estirarse, entrecruzarse o confundirse con motivos decorativos y roleos, de acuerdo con el esquema más conveniente en cada caso. Además, su naturaleza híbrida y en no pocos casos monstruosa, proporciona al artista un interesante campo para desplegar la fantasía o el más fabuloso delirio.

Los diseños para las criaturas marinas que aparecen en las armaduras del Renacimiento se basaron, a través de los grabados, tanto en prototipos iconográficos clásicos como en obras medievales, de acuerdo con el nivel de conocimientos de mitología que la época proporcionaba, y, también, según los modelos artísticos en los que los artistas se podían inspirar. Ya hemos señalado que las fuentes arqueológicas y artísticas parecen más acordes con el modelo clásico que las fuentes dadas por los mitógrafos del momento, pero también éstas dejan vislumbrar que los prototipos dados por el arte medieval, especialmente los manuscritos iluminados, fueron patrones a seguir. Las imágenes de las sirenas son buen ejemplo de esa dualidad de inspiración formal a la que nos referimos. Símbolos y formas fueron materialización de la herencia cultural mediterránea, asimilada y filtrada por los artistas, que eligieron la temática que mejor convenía a sus propósitos.

Tanto la época de Carlos V como la de su sucesor, Felipe II, constituyen un momento en el que la iconografía de los seres marinos tuvo un gran predicamento. Ya hemos apuntado que con Carlos V, los delfines fueron los motivos más recurrentes, por la riqueza de su simbología. Fue también en este reinado cuando la moda de la decoración al grutesco alcanzó su momento culminante.

En la iconografía elegida por Felipe II, distinta a la de su padre, puede observarse que los motivos marinos se mantuvieron vigentes, siguiendo los prototipos dados por las artes plásticas de la segunda mitad del siglo XVI, especialmente estampas, dibujos, escultura y pintura al fresco. De esta suerte, las armaduras muestran escenas más elaboradas, donde las luchas de centauros marinos y complejas figuraciones del thíasos clásico pasan a ser los asuntos más abordados. Quizás ello pueda explicarse en el hecho de que la segunda mitad del siglo XVI fue el momento en el que triunfó, definitivamente, la iconografía en la que se recreaba la mitología clásica, particularmente en la obra de los seguidores de Rafael.

A través de la evolución de la iconografía de asunto marino en la colección que hemos estudiado puede vislumbrarse, también, la asimilación plástica e ideológica del Renacimiento, su momento culminante, y su disolución, como preparación del Barroco, por lo que reivindicamos en nuestra idea inicial: las armaduras como obras bellas que no deberían seguir pasando desapercibidas para muchos historiadores del arte.

* Figuras nº 4-19 cedidas por Patrimonio Nacional, Madrid.

MARÍA ISABEL RODRíGUEZ LÓPEZ

Universidad Alfonso X el Sabio, miroguez@uax.es 